\title{
Removal of heavy metals from emerging cellulosic low-cost adsorbents: a review
}

\author{
D. S. Malik ${ }^{1}$ C. K. Jain ${ }^{2}$ Anuj K. Yadav ${ }^{1}$
}

Received: 7 October 2015/Accepted: 7 March 2016/Published online: 4 April 2016

(c) The Author(s) 2016. This article is published with open access at Springerlink.com

\begin{abstract}
Heavy metal pollution is a major problems in the environment. The impact of toxic metal ions can be minimized by different technologies, viz., chemical precipitation, membrane filtration, oxidation, reverse osmosis, flotation and adsorption. But among them, adsorption was found to be very efficient and common due to the low concentration of metal uptake and economically feasible properties. Cellulosic materials are of low cost and widely used, and very promising for the future. These are available in abundant quantity, are cheap and have low or little economic value. Different forms of cellulosic materials are used as adsorbents such as fibers, leaves, roots, shells, barks, husks, stems and seed as well as other parts also. Natural and modified types of cellulosic materials are used in different metal detoxifications in water and wastewater. In this review paper, the most common and recent materials are reviewed as cellulosic low-cost adsorbents. The elemental properties of cellulosic materials are also discussed along with their cellulose, hemicelluloses and lignin contents.
\end{abstract}

Keywords Heavy metals - Cellulosic low-cost adsorbents - Wastewater treatment technologies . Adsorption

Anuj K. Yadav

anujyadav2007@rediffmail.com

1 Department of Zoology and Environmental Sciences, Gurukula Kangri Vishwavidyalaya, Haridwar (U.K.) 249404, India

2 Environmental Hydrology Division, National Institute of Hydrology, Roorkee (U.K.) 247667, India

\section{Introduction}

Heavy metals are elements which have atomic density more than 5. Some toxic heavy metals, such as lead, cadmium, nickel, cobalt, chromium, arsenic, iron and zinc, cause metal toxicity in living organisms. The major metal polluting industries are tannery, electroplating, textile, fertilizer, pesticide and metal processing industries as well as mining sectors. These toxic metals are major pollutants of freshwater reserves (Babarinde et al. 2006). Most of the metals are non-biodegradable, highly toxic and carcinogenic in nature. Toxic heavy metals reach through various food chains and cause toxic effects on the ecosystem as well as humans and animals. Therefore, it is necessary to treat metal-contaminated wastewater before its discharge into the environment.

A number of technologies are available to treat heavy metal-laden wastewater. Among them, some popular techniques are chemical precipitation (Ku and Jung 2001), ion exchange (Alyüz and Veli 2009), adsorption (Park et al. 2007; Kongsuwan et al. 2009; Guo et al. 2010), ultrafiltration (Landaburu-Aguirre et al. 2009; Sampera et al. 2009), reverse osmosis (Shahalam et al. 2002; Mohsen-Nia et al. 2007), nanofiltration (Murthy and Chaudhari 2008; Muthukrishnan and Guha 2008; Nguyen et al. 2009; Figoli et al. 2010), electrodialysis (Sadrzadeha et al. 2009; Nataraj et al. 2007), coagulation (El Samrani et al. 2008; Chang and Wang 2007), flocculation (Chang et al. 2009; Duan et al. 2010; Bratskaya et al. 2009), flotation (Lundh et al. 2000; Polat and Erdogan 2007) and electrochemical process (Heidmann and Calmano 2008; Nanseu-Njiki et al. 2009). Comparatively, the adsorption process seems to be a significant technique due to its wide applications, such as ease of operation, economical feasibility, wide availability and simplicity of design (Faust and Aly 1987). 
For cellulosic low-cost biosorbents, agricultural waste or plant wastes are mostly used in heavy metal sequestration, due to their low economic value and widespread availability, and also the potential to treat wastewater at a large scale. The cellulosic plant materials used in heavy metal detoxification are rice husk (Sobhanardakani et al. 2013; Nakbanpote et al. 2000; Feng et al. 2006), wheat straw (Farooq et al. 2011, Dang et al. 2009; Dhir and Kumar 2010; Pehlivan et al. 2009a, b, c), banana peel (Memon et al. 2009; Sahu et al. 2013; Ajmal et al. 2000), grape bagasse (Farinella et al. 2007), corn stalk (Zheng et al. 2012), bel fruit shells (Anandkumar and Mandal 2009), coir pith (Parab et al. 2006), hemp fibers (Tofan et al. 2013) and corn cob (Buasri et al. 2012).

In the category of low-cost adsorbents, both non-cellulosic and cellulosic materials are used. In non-cellulosic materials, zeolites (Basaldella et al. 2007), clay (Adebowale et al. 2006), chitosan (Gamage and Shahidi 2007), red mud (Nadaroglu et al. 2010), dairy sludges (Sassi et al. 2010) and metal oxides (Mishra et al. 2004) are utilized as adsorbents. The use of cellulosic waste materials as adsorbent is considered as promising in the future. The main sources of cellulosic contents are agricultural waste material and industrial by-products. Non-agricultural wastes are also prominent, because these are also efficient in metal removal, as presented by many current studies.

In this review, cellulosic emerging modified or natural adsorbents has been characterized with the lignocellulosic and composite properties of widely used materials. The potential of cellulosic adsorbent materials for various heavy metal uptake capacities was also reported.

\section{Techniques used in heavy metal removal}

Many techniques are used at the present time for wastewater treatment. The present study will summarize the widely used technique for heavy metal removal from wastewater. For treatment of waste water, many methods are common, viz. precipitation, neutralization, membrane filtration, ion exchange, flotation and adsorption. Both, physical and chemical treatment technologies have been developed, such as the electrochemical process (Vlyssides and Israilides 1997), coagulation/flocculation (Song et al. 2006), oxidation (Szpyrkowicz et al. 2001), reverse osmosis (Hanra and Ramchandran 1996), membrane filtration (Sabry et al. 2007) and adsorption (Nagah and Hanafiah 2008) for treatment of different types of water. Among these, adsorption technology is the least expensive and effective separation technique for the removal of metal ions from industrial wastewater (Demirbas et al. 2008a, b).

\section{Chemical precipitation}

It is a simple and very common technique to remove heavy metals due to its ease in operation and inexpensive nature ( $\mathrm{Ku}$ and Jung 2001). Chemical precipitation technique is used for the treatment of metal-containing wastewater by forming an insoluble precipitate through the addition of chemicals (Karthikeyan et al. 1996). Some other chemical precipitation techniques are also used such as hydroxide precipitation, sulfide precipitation and heavy metal chelating precipitation. As precipitant agents, lime and limestones are most commonly used in chemical precipitation due to being a simple process, convenience and effectiveness in treating inorganic effluents at higher concentrations (Mirbagherp and Hosseini 2004; Aziz et al. 2008). Despite the advantages, it also has some disadvantages, such as requiring an excess amount of chemicals in the treatment. It has some other drawbacks such as generation of excessive sludge and the problem of sludge disposal into the environment.

\section{Ion exchange}

The ion exchange method is basically based on the capability to exchange cations with metals in the wastewater (Maranon et al. 1999; Kononova et al. 2000; Monteagudo and Ortiz 2000; Pagano et al. 2000). There are different types of materials used, which may be natural (alumina, carbon, silicates) or synthetic (zeolites and resins). Among them, zeolites are most abundantly used in the ion exchange process (Fernandez et al. 2005). The ion exchange process takes place by both cations and anions exchange in aqueous medium by ion exchange. The drawback of this method is that it is highly sensitive to the $\mathrm{pH}$ of the solution, and the ion exchange is non-selective in operation.

\section{Membrane process}

The membrane filtration technique used different types of membranes and removal of various heavy metals in aqueous solution. This technique removes oils, suspended solids, heavy metals, and organic and inorganic materials (Barakat 2011; Fu and Wang 2011). Different forms of this technique are used based on the size of the particles, such as ultrafiltration (UF), nanofiltration (NF), reverse osmosis (OS) and electrodialysis (ED), depending on the type of wastewater.

\section{Ultrafiltration}

In this method, dissolved molecules, heavy metal ions and other contaminants are filtered using a membrane, 
according to their molecular size. Different types of membranes allow only the passage of low molecular solutes, and the remaining ones, such as larger molecules and heavy metals, do not pass through and are separated out. It has also been divided into subcategories, such as micellar enhanced ultrafiltration (Landaburu-Aguirre et al. 2012; Yurlova et al. 2002), complexation-ultrafiltration (Molinari et al. 2008) and chelating enhanced ultrafiltration (Kryvoruchko et al. 2002).

\section{Nanofiltration}

Nanofiltration is membrane separation technique that is used in heavy metal separation from aqueous solutions (Mohammad et al. 2004; Al-Rashdi et al. 2011). It is applied to the removal of different heavy metals such as copper (Cséfalvay et al. 2009; Ahmad and Ooi 2010), arsenic (Nguyen et al. 2009; Figoli et al. 2010), nickel (Murthy and Chaudhari 2008) and chromium (Muthukrishnan and Guha 2008). It is reliable, comparatively easy to operate and has low energy consumption than others (Erikson 1988).

\section{Reverse osmosis}

Reverse osmosis (RO) technique is used mainly for the separation and fractionation of organic and inorganic substances and heavy metals in aqueous and nonaqueous solutions. The RO technique can be used to treat different types of industrial effluents, viz., chemical, textile, petrochemical, electrochemical, food, paper and tannery industries (Mohsen-Nia et al. 2007). In combination with the pilot membrane reactor, this technique is efficient in metal removal at high level (Dialynas and Diamadopoulos 2009). It has some disadvantages also: it consumes high power for the pumping pressure and the restoration of the membrane.

\section{Electrodialysis}

Electrodialysis (ED) is a separation process in which dissolved ions are removed from one solution to another solution across a charged membrane under an electric field (Sadrzadeh et al. 2008; Mohammadi et al. 2005). It is used in the treatment of wastewater as well as in the production of drinking water from seawater, separation and recovery of heavy metals ions and in salt production (Sadrzadeha et al. 2009). It is applied for heavy metal removal, such as chromium (Nataraj et al. 2007), copper and ferrous (Cifuentes et al. 2009), by various researchers.

\section{Flotation}

Flotation has been widely applied for the removal of toxic metal ions from wastewater (Polat and Erdogan 2007;
Waters 1990; Tassel et al. 1997; Tessele et al. 1998). Other techniques of flotation are ion flotation, dissolved air flotation (DAF) and precipitate flotation. DAF is a more commonly used process than any other flotation techniques in the removal of heavy metals from aqueous solutions (Zabel 1984).

\section{Chemical coagulation}

Coagulation technique is used to prepare colloids. Some coagulates are used, such as aluminum, ferrous sulfate and ferric chloride that neutralize impurities present in wastewater/water. It is an important method showed by various researchers (El Samrani et al. 2008; Chang and Wang 2007). Ferric chloride solution and polyaluminium chloride (PAC) coagulants are used in heavy metal removal (El Samrani et al. 2008).

\section{Electrochemical method}

Electrochemical methods involves the redox reactions for metal removal under the influence of external direct current in the electrolyte solution. The coagulation process destabilizes colloidal particles by adding a coagulant and results in the sedimentation process (Shammas 2004). For increase in the rate of coagulation, the flocculation process takes place which enhances the change of unstable particles into bulky floccules (Semerjian and Ayoub 2003).

\section{Adsorption}

Adsorption is a very significantly economic, convenient and easy operation technique. It shows high metal removal efficiency and is applied as a quick method for all types of wastewater treatments. It is becoming a popular technique, because in this process the adsorbent can be reused and metal recovery is possible (Barakat 2011; Fu and Wang 2011; Zamboulis et al. 2011).

\section{Activated carbon (AC)}

At present, activated carbon (AC) is the mostly used adsorbent worldwide. AC is not only efficient in removal of heavy metals, but also for other contaminants present in water/wastewater. These can be used in both batch and column mode operation due to its high surface area, microporous structure and porosity properties. In the preparation of activated carbon, many agricultural waste biomasses are used such as bagasse (Onal et al. 2007), coconut shell, tea waste, peanut hull (Oliveira et al. 2009), apple waste (Maranon and Sastre 1991), sawdust (Ajmal et al. 1998), rice husk (Naiya et al. 2009), banana pith (Low et al. 1995), tree bark (Gundogdu et al. 2009) and activated 
cotton fibers (Kang et al. 2008). The adsorption capacity of the lignocellulosic material can be increased by physical and chemical modification of adsorbents. It is costly in nature at the industrial level. So, researchers are focusing on the use of low-cost adsorbents for the treatment operation.

\section{Low-cost adsorbents}

With the availability and cheapness of various waste materials, industrial by-products, agricultural wastes and other natural waste materials, the low-cost technique has become popular nowadays. The focus on selecting low-cost adsorbent is because of the high cost of commercially activated carbon. Researchers are preparing industrial by-products as low cost adsorbents, such as pulp and paper waste (Stniannopkao and Sreesai 2009), fertilizer waste (Gupta et al. 1997), steel converter slag (Mendez et al. 2009), steel making slag (Kim et al. 2008), sugarcane bagasse (Soliman et al. 2011), bagasse fly ash (Gupta and Ali 2000; Rao et al. 2002; Gupta et al. 2010) that are very common. Household wastes such as fruit waste (Kelly-Vargas et al. 2012), marine origin adsorbent such as peat (Brown et al. 2000; Márquez-Reyes et al. 2013) and red mud (Sahu et al. 2013; Bertocchi et al. 2006; Gupta et al. 2001) are also used in the treatment. Nonagricultural adsorbents are also used as low-cost adsorbents such as lignin (Betancur et al. 2009; Reyes et al. 2009), diatomic (Sheng et al. 2009), clino-pyrrhotite (Lu et al. 2006), aragonite shells (Kohler et al. 2007), natural zeolites (Apiratikul and Pavasant 2008), clay (Al-Jlil and Alsewailem 2009), kaolinite (Gu and Evans 2008) and peat (Liu et al. 2008).

\section{Bioadsorbents}

Mostly agricultural and plant wastes were used as bioadsorbents for wastewater treatment; these are very efficient and promising in the biosorption technique. There are generally three types based on the sources:(1) non-living biomass such as bark, lignin, shrimp, krill, squid, crab shell, etc.; (2) algal biomass; (3) microbial biomass, e.g., algae, bacteria, fungi and yeast.

Agricultural wastes in the preparation of bioadsorbents are also promising such as potato peel (Aman et al. 2008), sawdust (Ajmal et al. 1998; Kaczala et al. 2009), citrus peels (Schiewer and Patil 2008), mango peel (Iqbal et al. 2009a, b), corn cob (Leyva-Ramos et al. 2005; Vaughan et al. 2001), rice husk (Chockalingam and Subramanian 2006), tree fern (Ho 2003), wheat bran (Ozer and Ozer 2004), grape bagasse (Farinella et al. 2007), coconut copra meal (Ho and Ofomaja 2006), orange waste (Dhakal et al. 2005), walnut, hazelnut, almond shell (Pehlivan and Altun 2008), tea waste (Malkoc and Nuhoglu 2005), dried parthenium powder (Ajmal et al.
2006), sugarcane bagasse (Khan et al. 2001; Mohan and Singh 2002), pine needles (Dakiky et al. 2002), peanut shell (Namasivayam and Periasamy 1993), tamarind seeds (Gupta and Babu, 2009), sunflower stalk (Sun and Xu 1997) and black gram husk (Saeed et al. 2005).

\section{Characterization of cellulosic waste material}

Bioadsorbents are composed of mainly cellulose, hemicelluloses, lignin and extractives, and many other compounds such as lipid, starch, hydrocarbons, simple proteins and ash (Sud et al. 2008).

\section{Cellulose}

Cellulose $\left(\mathrm{C}_{5} \mathrm{H}_{8} \mathrm{O}_{4}\right)_{\mathrm{m}}$ is a long linear polysaccharide polymer consisting of $\beta-(1,4)$ linked glucose units. It is an important constituent of plant cell wall. It is present in plant cell combined with hemicelluloses and lignin. It is generally insoluble in water. The material with high cellulose contents are plant fibers, woods, stalks, stems, shells, straw, grasses, etc. (Table 1; Fig. 1).

\section{Hemicelluloses}

Hemiceluloses $\left(\mathrm{C}_{5} \mathrm{H}_{8} \mathrm{O}_{4}\right)_{\mathrm{m}}$ are another important constituent of plants materials. Hemicellulose is a dietary fiber consisting of a heterogenous group of polysaccharide substances that contain a number of sugars including xylose, mannose, galactose, arabinose and glucuronic acids. These are generally insoluble in water, but some hemicelluloses containing acids are water soluble. The materials with high hemicellulosic contents are barks, leaves, grasses, corn cobs, husks and shells (Table 1).

\section{Lignin}

Lignin $\left[\mathrm{C}_{9} \mathrm{H}_{10} \mathrm{O}_{3}\left(\mathrm{OCh}_{3}\right) 0.9-1.7\right]_{n}$ is a highly branched polymer consisting of phenol units which include transconiferyl, trans-sinapyl and trans-p-coumaryl. It is also insoluble in water and has both characteristics of dietary and functional fibers. It is mostly present in the stems, seeds of vegetables and fruits and cereals. The materials with high lignin contents are cereal material husks, others shells, leaves, barks, grasses and fruit seeds (Table 1).

\section{Extractives}

Extractives are organic materials and generally soluble in neutral solvents which includes resin, fats, alcohols, turpentine, tannins, fatty acids, waxes and flavonoids (Demirbas 2008a, b). 
Table 1 Lignocellulosic contents in plant material

\begin{tabular}{|c|c|c|c|c|c|}
\hline Plant materials & $\begin{array}{l}\text { Cellulose } \\
(\%)\end{array}$ & $\begin{array}{l}\text { Hemicellulose } \\
(\%)\end{array}$ & $\begin{array}{l}\text { Lignin } \\
(\%)\end{array}$ & $\begin{array}{l}\text { Extractive } \\
(\%)\end{array}$ & References \\
\hline \multicolumn{6}{|l|}{ Husk } \\
\hline Coconut husks & 40.0 & 0.2 & 43.0 & 5.5 & Reddy and Yang (2005) \\
\hline Millet husks & 44.9 & 36.2 & 18.9 & 12.7 & Raveendran et al. (1995) \\
\hline Olive husks & 25.0 & 24.6 & 50.4 & 8.9 & Kristensen (1996) and Demirbas (2004) \\
\hline Rice husks & 43.8 & 31.6 & 24.6 & 6.67 & Raveendran et al. (1995), Kristensen (1996) and Nakbanpote et al. (2000) \\
\hline \multicolumn{6}{|l|}{ Shell } \\
\hline Almond shells & 50.7 & 28.9 & 20.4 & 2.4 & Demirbas (2004) \\
\hline Almond shells & 28.99 & 35.16 & 30.01 & 5.0 & Pehlivan et al. (2009a, b, c) \\
\hline Coconut shells & 40.3 & 27.8 & 31.9 & 8.4 & Raveendran et al. (1995) \\
\hline Coconut shells & 14.0 & 32.0 & 46.0 & - & Cagnon et al. (2009) \\
\hline Dende shells & 24.9 & 27.0 & 45.4 & 1.1 & Ouensanga et al. (2003) \\
\hline Hazelnut shells & 26.6 & 30.0 & 43.4 & 3.9 & Demirbas $(2004,2009)$ \\
\hline Hazelnut shells & 18.24 & 28.90 & 48.57 & 4.83 & Pehlivan et al. (2009a, b, c) \\
\hline Peanut shells & 42.2 & 22.1 & 35.7 & 10.9 & Raveendran et al. (1995) \\
\hline Walnut shells & 28.1 & 26.6 & 45.3 & 2.7 & Demirbas (2004) and Prasad et al. (2007) \\
\hline \multicolumn{6}{|l|}{ Straws } \\
\hline Barley straw & 48.6 & 29.7 & 21.7 & 14.8 & $\begin{array}{l}\text { Sander (1997), Abbasi and Abbasi (2010), Naik et al. (2010) and Tamaki } \\
\text { and Mazza (2010) }\end{array}$ \\
\hline Legume straw & 29.2 & 35.5 & 35.3 & 3.8 & Demirbas (2009) \\
\hline Rice straw & 52.3 & 32.8 & 14.9 & 9.3 & $\begin{array}{l}\text { Raveendran et al. (1995), Kristensen (1996), Prasad et al. (2007), Demirbas } \\
\text { (2009) and Abbasi and Abbasi (2010) }\end{array}$ \\
\hline Rice straw & 43.3 & 25.1 & 5.4 & 13.1 & Wartelle and Marshall (2006) \\
\hline Rye straw & 49.9 & 29.6 & 20.5 & 11.0 & Sander (1997) and Abbasi and Abbasi (2010) \\
\hline Wheat straw & 44.5 & 33.2 & 22.3 & 12.4 & $\begin{array}{l}\text { Raveendran et al. (1995), Kristensen (1996), Sander (1997), McKendry } \\
\text { (2002), Demirbas (2004), Prasad et al. (2007), Abbasi and Abbasi } \\
\text { (2010), Naik et al. (2010) and Tamaki and Mazza (2010) }\end{array}$ \\
\hline Wheat straw & 31.5 & 33.3 & 11.6 & & Chen et al. (2008) \\
\hline \multicolumn{6}{|l|}{ Stems/woods } \\
\hline Albizzia wood & 59.5 & 6.7 & 33.8 & 1.9 & Kataki and Konwer (2001) \\
\hline Birch & 50.2 & 32.8 & 17.0 & 3.0 & Kristensen (1996), Tillman and Harding (2004) and Shen et al. (2009) \\
\hline Eucalyptus & 52.7 & 15.4 & 31.9 & 2.2 & Huber et al. (2006) \\
\hline Oak & 58.4 & 31.4 & 10.2 & & Shen et al. (2009) \\
\hline Pine & 48.1 & 23.5 & 28.4 & 3.9 & $\begin{array}{l}\text { Kristensen (1996), Tillman and Harding (2004), Huber et al. (2006) and } \\
\text { Shen et al. (2009) }\end{array}$ \\
\hline Softwood & 43.3 & 27.4 & 29.3 & & Kristensen (1996), McKendry (2002) and Demirbas (2009) \\
\hline Spruce & 43.6 & 27.4 & 29.0 & 1.8 & Tillman and Harding (2004) \\
\hline \multicolumn{6}{|l|}{ Leaves } \\
\hline Albizzia leaves & 25.3 & 44.6 & 30.1 & 3.0 & Kataki and Konwer (2001) \\
\hline Premna leaves & 30.3 & 50.8 & 18.9 & 4.6 & Kataki and Konwer (2001) \\
\hline $\begin{array}{l}\text { Pterospermum } \\
\text { leaves }\end{array}$ & 22.1 & 50.6 & 27.3 & 3.7 & Kataki and Konwer (2001) \\
\hline $\begin{array}{l}\text { Syzygium } \\
\text { leaves }\end{array}$ & 28.1 & 42.9 & 29.0 & 3.3 & Kataki and Konwer (2001) \\
\hline \multicolumn{6}{|l|}{ Barks } \\
\hline Albizzia bark & 22.5 & 44.9 & 32.6 & 4.5 & Kataki and Konwer (2001) \\
\hline Premna bark & 19.0 & 60.4 & 20.6 & 2.6 & Kataki and Konwer (2001) \\
\hline $\begin{array}{l}\text { Pterospermum } \\
\text { bark }\end{array}$ & 20.7 & 53.2 & 26.1 & 3.1 & Kataki and Konwer (2001) \\
\hline Syzygium bark & 22.6 & 46.4 & 31.0 & 3.0 & Kataki and Konwer (2001) \\
\hline
\end{tabular}


Table 1 continued

\begin{tabular}{|c|c|c|c|c|c|}
\hline Plant materials & $\begin{array}{l}\text { Cellulose } \\
(\%)\end{array}$ & $\begin{array}{l}\text { Hemicellulose } \\
(\%)\end{array}$ & $\begin{array}{l}\text { Lignin } \\
(\%)\end{array}$ & $\begin{array}{l}\text { Extractive } \\
(\%)\end{array}$ & References \\
\hline \multicolumn{6}{|l|}{ Grasess } \\
\hline Bamboo & 43.9 & 26.5 & 29.6 & 2.8 & Scurlock et al. (2000) and Abbasi and Abbasi (2010) \\
\hline Bermuda grass & 37.3 & 53.2 & 9.5 & & Prasad et al. (2007) \\
\hline Elephant grass & 31.5 & 34.3 & 34.2 & & Abbasi and Abbasi (2010) \\
\hline Orchard grass & 41.7 & 52.2 & 6.1 & 23.3 & Demirbas (2009) and Abbasi and Abbasi (2010) \\
\hline Rye grass & 49.1 & 41.4 & 9.5 & & Abbasi and Abbasi (2010) \\
\hline $\begin{array}{l}\text { Sweet sorghum } \\
\text { grass }\end{array}$ & 50.6 & 24.7 & 25.0 & & Huber et al. (2006) \\
\hline Timothy grass & 38.0 & 33.1 & 28.9 & & Naik et al. (2010) \\
\hline \multicolumn{6}{|l|}{ Stalks } \\
\hline Corn stalk & 49.0 & 37.9 & 13.1 & 10.5 & Raveendran et al. (1995), Kristensen (1996) and Yanik et al. (2007) \\
\hline Cotton stalk & 62.2 & 18.4 & 15.4 & & Yanik et al. (2007) \\
\hline Sorghum stalk & 27.0 & 25.0 & 11.0 & & Reddy and Yang (2005) \\
\hline $\begin{array}{l}\text { Sunflower } \\
\text { stalk }\end{array}$ & 58.8 & 23.8 & 17.4 & 13.1 & Yanik et al. (2007), Pettersson et al. (2008) \\
\hline \multicolumn{6}{|l|}{ Fibers } \\
\hline Flax fiber & 75.9 & 20.7 & 3.4 & 25.6 & Williams and Reed (2006) \\
\hline Jute bust fiber & 53.3 & 21.2 & 25.5 & & Abbasi and Abbasi (2010) \\
\hline $\begin{array}{l}\text { Kenaf bast } \\
\text { fiber }\end{array}$ & 47.0 & 30.2 & 22.8 & & Abbasi and Abbasi (2010) \\
\hline $\begin{array}{l}\text { Pineapple leaf } \\
\text { fiber }\end{array}$ & $70-80$ & 18.0 & $5-12$ & 0.8 & Reddy and Yang (2005) \\
\hline \multicolumn{6}{|l|}{ Seeds/hulls } \\
\hline $\begin{array}{l}\text { Cotton seed } \\
\text { hull }\end{array}$ & 48.7 & 18.5 & 22.3 & 1.1 & Wartelle and Marshall (2006) \\
\hline Guava seeds & 28.0 & 15.5 & 41.7 & 16.8 & Ouensanga et al. (2003) \\
\hline Jujube seeds & 37.3 & 25.9 & 35.4 & 0.3 & Ouensanga et al. (2003) \\
\hline \multicolumn{6}{|l|}{ Pulps } \\
\hline Apple pulp & 16.0 & 16.0 & 21.0 & & Cagnon et al. (2009) \\
\hline Plum pulp & 6.5 & 14.5 & 39.0 & & Cagnon et al. (2009) \\
\hline \multicolumn{6}{|l|}{ Bagasse } \\
\hline Olive baggase & 31.1 & 15.6 & 25.21 & 28.09 & Demiral et al. (2011) \\
\hline \multicolumn{6}{|l|}{ Others } \\
\hline Corn cob & 38.4 & 40.7 & 9.1 & 1.3 & Feng et al. (2006) \\
\hline $\begin{array}{l}\text { Ectodermus of } \\
\text { opuntia }\end{array}$ & 28.2 & 14.4 & 14.5 & & Barrera et al. (2006) \\
\hline Holm oak & 37.9 & 25.9 & 27.8 & 4.8 & López et al. (2013) \\
\hline Newspaper & $40-55$ & $25-40$ & $18-30$ & & Chandra et al. (2012) \\
\hline Pyrenean oak & 33.9 & 25.5 & 31.2 & 5.2 & López et al. (2013) \\
\hline Stone pine & 41.0 & 20.1 & 31.2 & 6.8 & López et al. (2013) \\
\hline
\end{tabular}

\section{Properties of cellulosic low-cost adsorbents}

Low-cost cellulosic biomass properties are generally proximate analysis, ultimate analysis and compositional properties. These properties show the variation of its constituents derived from different plant and agricultural waste.

\section{Proximate properties}

It generally shows the variation in fixed carbon, volatile matter, moisture and ash content in plant and agricultural materials (Table 2). 


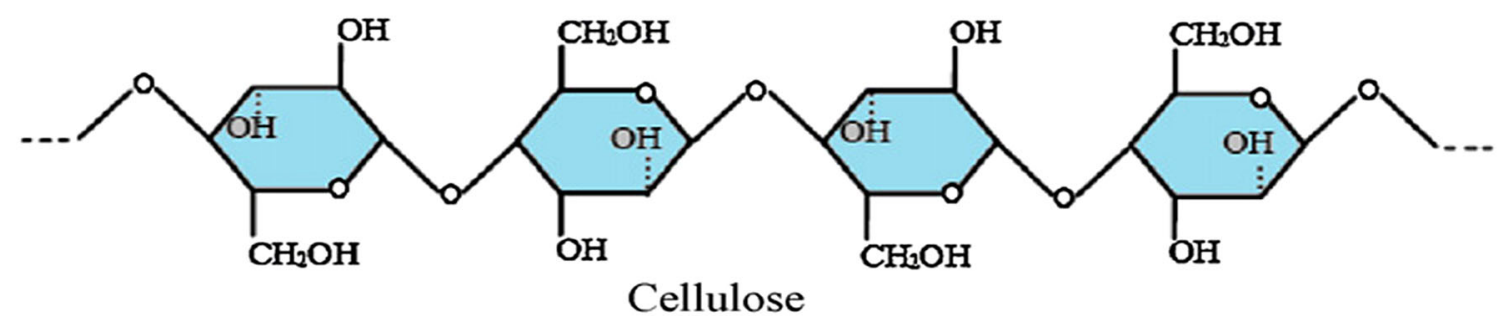

Fig. 1 Structure of cellulose (Chandra et al. 2012)

\section{Ultimate properties}

It gives the information about the elemental knowledge of a particular biomass followed by oxygen content, hydrogen content, nitrogen content and sulfur content (Table 3).

\section{Compositional properties}

The compositional properties of cellulosic adsorbents are characterrized with parameters like cellulose content, hemicelluloses content and lignin content.

\section{Adsorption characteristics of cellulosic low-cost adsorbents}

In the removal of metals from aqueous solution, different types of plant parts are used such as stems, stalks, leaves, husk, shells, roots, and barks and many others. These are freely and easily available, because India is rich in plant biomass. Agricultural plant materials are very common in the preparation of low-cost adsorbents. Most of the countries are rich in plant biodiversity and have large agricultural areas.

\section{Husks}

Rice is a crop that is cultivated all over the world. The hard outer covering of the grains of rice is a waste material generated from the rice milling process. In the world, rice is the major source of food calorie and livelihood. It is grown worldwide in most of the countries such as China, India and Indonesia. There is the problem of utilization of rice husk in rice-growing countries. Lignocellulogic agricultural waste material contains approximately $35 \%$ cellulose, $25 \%$ hemicelluloses, $20 \%$ lignin, $17 \%$ silica (including ash) and $3 \%$ crude protein. It has been used widely in heavy metal removal from aqueous solutions (Ajmal et al. 2003; Bishnoi et al. 2004; Dadhlich et al. 2004). Sobhanardakani et al. 2013 applied untreated rice husk for removal of $\mathrm{Cr}$ (III) and $\mathrm{Cu}$ (II) from synthetic wastewater. He achieved the maximum sorption capacity

Table 2 Proximate analysis of cellulosic materials/biomass (\%wt.)

\begin{tabular}{|c|c|c|c|c|c|}
\hline Plant material & Fixed carbon & Ash & Volatile matter & Moisture & References \\
\hline Cashew nut shell & 22.21 & 2.75 & 65.25 & 9.83 & Kumar et al. (2012a, b) \\
\hline Holm oak & 7.4 & 2.3 & 80.8 & 9.5 & López et al. (2013) \\
\hline Moringa oleifera bark & 20.1 & 11.1 & & 2.5 & Reddy et al. (2011) \\
\hline Mangifera indica sawdust & 16.28 & 8.32 & 66.0 & 9.4 & Kapur and mondal (2013) \\
\hline Olive bagasse & 21.6 & 4.4 & 67.2 & & Sensöz et al. (2006) \\
\hline Peanut shell & 23.17 & 3.12 & 68.69 & 5.02 & AL-Othman et al. (2012) \\
\hline Pyrenean oak & 6.0 & 2.4 & 80.5 & 11.1 & López et al. (2013) \\
\hline Rice husk & & 17.1 & 59.5 & & Mahvi et al. (2004) \\
\hline Silver fir & 6.5 & 0.4 & 78.7 & 14.4 & López et al. (2013) \\
\hline Stone pine & 7.4 & 0.7 & 82.2 & 9.8 & López et al. (2013) \\
\hline Sugarcane bagasse & 7.0 & 22.1 & 70.9 & & Grover et al. (2002) \\
\hline Sugarcane leaves & 14.9 & 7.7 & 77.4 & & Grover et al. (2002) \\
\hline Sunflower waste carbon & & 3.8 & & 2.8 & Jain et al. (2013) \\
\hline Tea waste & & 4.8 & & 5.4 & Mondal (2010) \\
\hline Wheat straw & 11.7 & 7.7 & 77.4 & & Grover et al. (2002) \\
\hline
\end{tabular}


Table 3 Ultimate analysis of cellulosic biomass/material (\%wt.)

\begin{tabular}{|c|c|c|c|c|c|c|}
\hline Plant material & $\mathrm{C}$ & $\mathrm{H}$ & $\mathrm{N}$ & $S$ & $\mathrm{O}$ & References \\
\hline Almond shell & 48.17 & 5.89 & & & 45.93 & Pehlivan et al. (2009a, b, c) \\
\hline Cashew nut shells & 45.21 & 4.25 & 0.21 & & 37.75 & Kumar et al. (2011) \\
\hline Hazelnut shell & 48.92 & 5.65 & & & 45.42 & Pehlivan et al. (2009a, b, c) \\
\hline Holm oak & 48.0 & 5.9 & 0.5 & 0.02 & 45.6 & López et al. (2013) \\
\hline Jacaranda mimosifolia & 48.2 & 4.4 & 0.2 & & 47.2 & Trevino-Corderoa et al. (2013) \\
\hline Maize straw & 45.6 & 5.4 & 0.3 & 0.04 & 43.4 & Taner et al. (2004) \\
\hline Moringa oleifera bark & 44.8 & 5.9 & 0.8 & 0.9 & 47.6 & Reddy et al. (2011) \\
\hline Olive bagasse & 53.4 & 7.5 & 1.7 & & 37.4 & Sensöz et al. (2006) \\
\hline Peanut shell & 49.36 & 5.71 & 0.72 & & 44.42 & AL-Othman et al. (2012) \\
\hline Prunus domestica & 52.0 & 6.20 & 0.3 & & 45.2 & Trevino-Corderoa et al. (2013) \\
\hline Pyrenean oak & 48.5 & 5.9 & 0.5 & 0.01 & 45.1 & López et al. (2013) \\
\hline Silver fir & 51.2 & 6.4 & 0.2 & & 42.2 & López et al. (2013) \\
\hline Stone pine & 50.4 & 6.0 & 0.3 & 0.01 & 43.3 & López et al. (2013) \\
\hline Sugarcane leaves & 39.7 & 5.5 & & 0.2 & 46.8 & Grover et al. (2002) \\
\hline Sunflower waste carbon & 44.0 & 2.8 & 8.5 & & 44.7 & Jain et el. (2013) \\
\hline Tea waste & 57.6 & 8.25 & 0.42 & 0.52 & 33.1 & Mondal (2012) \\
\hline Wheat straw & 46.7 & 6.3 & 0.4 & 0.1 & 41.2 & Taner et al. (2004) \\
\hline
\end{tabular}

of 22.5 and $30 \mathrm{mg} / \mathrm{g}$, respectively. The adsorption capacities of different husk materials are in listed in Table 4.

It was reported that peanut husk modified with $\mathrm{Fe}$ and formaldehyde gives improve result. It was found that Femodified formaldehyde husk shows six times higher adsorption capacity than formaldehyde-modified peanut husk (Olguin et al. 2013). Wong et al. (2003) used tartaric acid-modified rice husk in the removal of $\mathrm{Cu}(\mathrm{II})$ and $\mathrm{Pb}(\mathrm{II})$ ions from aqueous solutions. He reported that the maximum metal uptake were found to be 29 and $108 \mathrm{mg} / \mathrm{g}$ at $27^{\circ} \mathrm{C}$ for $\mathrm{Cu}(\mathrm{II})$ and $\mathrm{Pb}(\mathrm{II})$ metal ions, respectively. Fixed bed column study was also performed by the phosphatetreated rice husk in the removal of $\mathrm{Pb}(\mathrm{II}), \mathrm{Cu}$ (II), $\mathrm{Zn}$ (II) and $\mathrm{Mn}(\mathrm{II})$ at different time intervals. Table 5 (Mohan and Sreelakshmi 2008) describes the operating conditions for column experiments.

It was investigated that the flow rate $20 \mathrm{ml} / \mathrm{min}$ is optimum for the $10 \mathrm{mg} / \mathrm{l}$ solution. The breakthrough time was find to increase from 1.3 to $3.5 \mathrm{~h}$ for $\mathrm{Pb}$ (II), 4.0 to $9.0 \mathrm{~h}$ for $\mathrm{Cu}(\mathrm{II}), 12.5$ to $25.4 \mathrm{~h}$ for $\mathrm{Zn}$ (II) and 3.0 to $11.3 \mathrm{~h}$ for $\mathrm{Mn}$ (II) for increasing bed height up to $10-30 \mathrm{~cm}$.

\section{Straw and bran}

The adsorbents prepared from straw and bran are commonly wheat straw and barley straw. Wheat straws have high worldwide production in some countries such as China, India and Russia. In 2013/14, the world wheat supplies increased from 5.3 million tons to 887.3 million tons (WASDE 2013). Wheat straw is commonly used mainly as cattle fodder. So it is needed to utilize wheat straw and bran for other applications also. The wheat straw is also lignocellulosic waste material that constitutes $\quad 34-40 \%$ cellulose, $20-35 \%$ hemicelluloses, 8-15\% lignin and sugars and other compounds (Keng et al. 2013). It was reported that wheat straw treated with microwave radiation gave significant results. It was found that the adsorption capacity was $39.22 \mathrm{mg} / \mathrm{g}$ (Farooq et al. 2011). The adsorption capacities of wheat straw and bran in heavy metal removal are given in Table 6.

Chojnacka (2006) investigated that ground straw removal of $\mathrm{Cr}$ (III) metal ions takes places when equilibrium is reached in less than $20 \mathrm{~min}$. Farooq et al. (2011) found that wheat straw followed Langmuir model with maximum biosorption capacity $\left(q_{\max }\right) \mathrm{mg} / \mathrm{g}$. The maximum sorption occurred at $\mathrm{pH} 6$ and the equilibrium time was 20 min. Barley husk showed the maximum sorption capacities of 69 and $88 \%$ for $\mathrm{Cu}(\mathrm{II})$ and $\mathrm{Pb}$ (II), respectively (Pehlivan et al. 2009a, b, c). It was found that the favorable $\mathrm{pH}$ values for the removal of $\mathrm{Cu}$ (II) and $\mathrm{Pb}$ (II) were 6.0 and 6.6, respectively. The Langmuir isotherm model was fit with the sorption equilibrium results. The equilibrium sorption obtained after $2 \mathrm{~h}$ and the adsorption capacities for $\mathrm{Cu}(\mathrm{II})$ and $\mathrm{Pb}$ (II) were $4.64 \mathrm{mg} / \mathrm{g}$ and $23.20 \mathrm{mg} / \mathrm{g}$, respectively (Pehlivan et al. 2009a, b, c). 
Table 4 Adsorption capacities of husk materials for the removal of heavy metals from water/wastewater

\begin{tabular}{lllll}
\hline Cellulosic materials & Type of adsorbent & Heavy metals & Adsorption capacity (mg/g) & References \\
\hline Peanut husk & $\mathrm{MB}\left(\mathrm{FeCl}_{3}\right.$ and formaldehyde) & $\mathrm{Cr}(\mathrm{VI})$ & 33.1 & Olguin et al. (2013) \\
Rice husk & $\mathrm{NB}$ & $\mathrm{Cd}(\mathrm{II})$ & 8.58 & Tan et al. (1993) \\
Rice husk & $\mathrm{NB}$ & $\mathrm{Ni}(\mathrm{II})$ & 102 & Feng et al. (2006) \\
Rice husk & $\mathrm{NB}$ & $\mathrm{Cr}(\mathrm{VI})$ & 45.6 & Scatchard (1949) \\
Rice husk & $\mathrm{NB}$ & $\mathrm{Cr}(\mathrm{III})$ & 1.90 & Marshall et al. (1993) \\
Rice husk & $\mathrm{NB}$ & $\mathrm{Cu}(\mathrm{II})$ & 7.1 & Nakbanpote et al. (2000) \\
Rice husk & $\mathrm{NB}$ & $\mathrm{Cr}(\mathrm{III})$ & 22.5 & Sobhanardakani et al. (2013) \\
Rice husk & $\mathrm{NB}$ & $\mathrm{Cu}(\mathrm{II})$ & 30.0 & Sobhanardakani et al. (2013) \\
\hline
\end{tabular}

$N B$ natural or unmodified biosorbent

Table 5 Operational parameter for column experiments

\begin{tabular}{ll}
\hline Column bed height & $10-30 \mathrm{~cm}$ \\
Column diameter & $2.5 \mathrm{~cm}$ \\
Weight of adsorbate uptake & $36 \mathrm{~g}$ \\
Volume of wastewater uptake & $501 \mathrm{ml}$ \\
Initial conc. & $10 \mathrm{mg} / \mathrm{l}$ \\
Flow rate & $20 \mathrm{ml} / \mathrm{min}$ \\
\hline
\end{tabular}

\section{Fruit peel/pulp}

The tropical as well as temperate countries produce different types of fruits depending on climatic variations. The peels of different types of fruits are considered as fruit waste material that can be used for biosorption of heavy metals in different wastewater (Table 7). The apple pulps constitute $16 \%$ cellulose, $16 \%$ hemicelluloses and $21 \%$ lignin (Cagnon et al. 2009). As biosorbent, orange peel indicates high metal adsorption potential due to its high content of cellulose, pectin (galacturonic acid), hemicelluloses and lignin (Feng et al. 2011). The adsorption of $\mathrm{Cr}(\mathrm{VI})$ ions from an aqueous solution of mosambi (sweet lime) peel dust has also been reported by Saha et al. 2013) without any prior modification. The adsorption of $\mathrm{Cr}(\mathrm{VI})$ was studied at different parameters such as sorbate concentration, $\mathrm{pH}$, contact time and temperature with the highest adsorption capacity of $250 \mathrm{mg} / \mathrm{g}$ (Table 7) at $\mathrm{pH}$ 2.0 and $40{ }^{\circ} \mathrm{C}$. The adsorption data was fit with the Langmuir isotherm that confirmed monolayer adsorption of hexavalent chromium on mosambi (sweet lime) peel.

Huang and Zhu (2013) prepared chemically modified biosorbent from muskmelon by the saponification process with alkaline solution of $\mathrm{Ca}(\mathrm{OH})_{2}$. They reported that the optimum equilibrium $\mathrm{pH}$ range for $100 \%$ adsorption 4-6.4. They also revealed the factor responsible for the uptake of metal ions was pectic acid present in muskmelon peel. The maximum adsorption capacities were found to be $0.81 \mathrm{~mol} / \mathrm{kg}$ for $\mathrm{Pb}$ (II) ions at equilibrium time of up to $10 \mathrm{~min}$. The use of sugar beet pulp for $\mathrm{Cr}(\mathrm{IV})$ removal was studied by Altundogan et al. (2007). The adsorbent was treated with sulfuric acid medium and sulfur dioxide gas reactant. The lower $\mathrm{pH}(2-3)$ was reported with the $24 \mathrm{mg} /$ g adsorption capacities at $25{ }^{\circ} \mathrm{C}$.

\section{Bagasse}

In the plant waste, bagasse is a very common waste material that was generated from the sugarcane industry as by-products (Table 8). It was used by Alomá et al. (2012)

Table 6 Adsorption capacities of straw materials for the removal of heavy metals from water/wastewater

\begin{tabular}{lllll}
\hline Cellulosic materials & Type of adsorbent & Heavy metals & Adsorption capacity (mg/g) & References \\
\hline Wheat straw & $\mathrm{NB}$ & $\mathrm{Cd}(\mathrm{II})$ & 14.56 & Dang et al. (2009) \\
Wheat straw & $\mathrm{NB}$ & $\mathrm{Cr}(\mathrm{VI})$ & 47.16 & Dhir and Kumar (2010) \\
Wheat straw & $\mathrm{NB}$ & $\mathrm{Cu}(\mathrm{II})$ & 11.43 & Dang et al. (2009) \\
Wheat straw & $\mathrm{NB}$ & $\mathrm{Ni}(\mathrm{II})$ & 41.84 & Dhir and Kumar (2010) \\
Wheat straw & $\mathrm{MB}$ (urea and microwave radiation) & $\mathrm{Cd}(\mathrm{II})$ & 39.22 & Farooq et al. (2011) \\
Wheat bran & $\mathrm{NB}$ & $\mathrm{Pb}(\mathrm{II})$ & 62.0 & Farajzadeh and Monji (2004) \\
Barley straw & $\mathrm{NB}$ & $\mathrm{Cu}(\mathrm{II})$ & 4.64 & Pehlivan et al. (2009a, b, c) \\
Barley straw & $\mathrm{NB}$ & $\mathrm{Pb}(\mathrm{II})$ & 23.2 & Pehlivan et al. (2009a, b, c)
\end{tabular}

$N B$ natural or unmodified biosorbent, $M B$ modified biosorbent 
in the removal of $\mathrm{Ni}(\mathrm{II})$ ions from the aqueous solution. The adsorption capacity for $\mathrm{Ni}(\mathrm{II})$ ion removal at $\mathrm{pH} 5$ at $25{ }^{\circ} \mathrm{C}$ was evaluated. The calculated sorption capacity was approximately $2 \mathrm{mg} / \mathrm{g}$. Adsorption followed Langmuir, Freundlich and sips isotherm models. They also reported that the Langmuir model represented data in a better way, with correlation coefficient greater than 0.95 .

Yu et al. (2013) used sugarcane bagasse modified with PMDA and unmodified form for the removal of heavy metals such as $\mathrm{Pb}^{2+}, \mathrm{Cd}^{2+}, \mathrm{Cu}^{2+}$ and $\mathrm{Zn}^{2+}$. It was found that adsorption of these four metal ions increased with an increasing solution $\mathrm{pH}$ and dosages. Langmuir isotherm model fit with equilibrium results. The adsorption capacities of modified bagasse were 1.06, 0.93, 1.21 and $1.0 \mathrm{mmol} / \mathrm{g}$ and for unmodified bagasse $0.04,0.13,0.10$, and $0.07 \mathrm{mmol} / \mathrm{g}$ for $\mathrm{Pb}^{2+}, \mathrm{Cd}^{2+}, \mathrm{Cu}^{2+}$ and $\mathrm{Zn}^{2+}$, respectively. FTIR and EDX studies also performed showed that the adsorption mechanism and kinetic process, pseudo-first order and pseudo-second order were also used to predict the adsorption rates.

\section{Stalk}

Plant stalks are cellulosic materials consisting of cellulose, hemicelluloses and lignin. Many plant stalk such as corn stalk (Zheng et al. 2012) and sunflower stalk (Sun and Shi 1998) are used for the removal of toxic metals (Table 9). Corn stalk as adsorbent was used after modification by graft polymerization for the removal of $\mathrm{Cd}(\mathrm{II})$ metal ion from aqueous solution (Zheng et al. 2012). The maximum adsorption of Cd(II) metal ion was found to be $21.37 \mathrm{mg} / \mathrm{g}$. They also reported that modified corn stalk had better potential of metal ion removal than unmodified corn stalk because of the addition of functional groups ( $-\mathrm{CN}$ and $\mathrm{OH}$ groups) and the lower crystallinity. Scanning electron microscopy (SEM), energy dispersive spectroscopy (SEMEDS, X-ray diffraction (XRD) and solid-state CP/MAS $\mathrm{C}^{13}$ NMR were used for characterization of adsorbents.

The feasibility of sunflower stalks for lead $(\mathrm{Pb})$ and cadmium $(\mathrm{Cd})$ metal ion adsorption has been investigated by Jalali and Aboulghazi (2013). Batch adsorption studies were conducted to study the effect of contact time, initial concentration (50 mg/l), pH (4-9) and adsorbent doses $(0.2-1.2 \mathrm{~g})$ on the removal of $\mathrm{Cd}(\mathrm{II})$ and $\mathrm{Pb}$ (II) metal ions at room temperature. The data fitted well with the modified two-site Langmuir model with maximum sorption capacities for $\mathrm{Pb}$ (II) and $\mathrm{Cd}(\mathrm{II})$ at optimum conditions of 182 and $70 \mathrm{mg} / \mathrm{g}$. The pseudo-second-order kinetic model fitted well with the rate constant $8.42 \times 10^{-12}$ and $8.95 \times 10^{2} \mathrm{~g} / \mathrm{mg} / \mathrm{m}$ for $\mathrm{Cd}$ and $\mathrm{Pb}$, respectively.

\section{Shell}

The effectiveness of lignocellulosic material as adsorbent from aqueous solution is due to the affinity between water molecule and cell wall components. These materials are highly porous and have a wide surface area. In the bioadsorbents as shell, coconut, bael fruit, cashew nut, oil palm, wheat and wood apple nd many others are used for various heavy metal removal (Table 10).

The biosorption of $\mathrm{Pb}(\mathrm{II})$ ions using hazelnut shells (NHS) and almond shells (AS) was investigated in batch experiments. Alkaline $\mathrm{pH}(6-7)$ was found to be favorable for the removal of metal ions. The uptake capacities were

Table 7 Adsorption capacities of fruit peel materials for the removal of heavy metals from water/wastewater

\begin{tabular}{lllll}
\hline Cellulosic materials & Type of adsorbrnt & Heavy metals & Adsorption capacity(mg/g) & References \\
\hline Banana peel & $\mathrm{NB}$ & $\mathrm{Cr}(\mathrm{VI})$ & 131.56 & Memon et al. (2009) \\
Banana peel & $\mathrm{NB}$ & $\mathrm{Cd}(\mathrm{II})$ & 35.52 & Memon et al. (2008) \\
Mango peel & $\mathrm{NB}$ & $\mathrm{Cd}(\mathrm{II})$ & 68.92 & Iqbal et al. (2009a, b) \\
Mango peel & $\mathrm{NB}$ & $\mathrm{Pb}(\mathrm{II})$ & 99.02 & Iqbal et al. (2009a, b) \\
Mango peel & $\mathrm{NB}$ & $\mathrm{Cu}(\mathrm{II})$ & 46.09 & Iqbal et al. (2009a, b) \\
Mango peel & $\mathrm{NB}$ & $\mathrm{Zn}(\mathrm{II})$ & 39.75 & Iqbal et al. (2009a, b) \\
Mango peel & $\mathrm{NB}$ & $\mathrm{Cr}(\mathrm{VI})$ & 28.21 & Iqbal et al. (2009a, b) \\
Mosambi (Sweet lime) peel & $\mathrm{NB}$ & $\mathrm{Ni}(\mathrm{II})$ & 150 & Saha et al. (2013) \\
Orange peel & $\mathrm{NB}$ & $\mathrm{Cd}(\mathrm{II})$ & 13.7 & Ajmal et al. (2000) \\
Orange peel & $\mathrm{MB}$ (nitric acid) & $\mathrm{Cu}(\mathrm{II})$ & 15.27 & Lasheen et al. (2012) \\
Orange peel & $\mathrm{MB}$ (nitric acid) & $\mathrm{Pb}(\mathrm{II})$ & 73.53 & Lasheen et al. (2012) \\
Orange peel & $\mathrm{MB}$ (nitric acid) & $\mathrm{Cr}(\mathrm{VI})$ & 24 & Lasheen et al. (2012) \\
Sugar beet pulp & $\mathrm{MB}$ ( $\left.\mathrm{H}_{2} \mathrm{SO}_{4}\right)$ & & Altundogan et al. (2007)
\end{tabular}

$N B$ natural or unmodified biosorbent, $M B$ modified biosorbent 
Table 8 Adsorption capacities of bagasse materials for the removal of heavy metals from water/wastewater

\begin{tabular}{lllll}
\hline Cellulosic materials & Type of adsorbent & Heavy metals & Adsorption capacity & References \\
\hline Grape bagasse & NB & $\mathrm{Cd}(\mathrm{II})$ & $0.774 \mathrm{mmol} / \mathrm{g}$ & Farinella et al. (2008) \\
Grape bagasse & $\mathrm{NB}$ & $\mathrm{Pb}(\mathrm{II})$ & $0.428 \mathrm{mmol} / \mathrm{g}$ & Farinella et al. (2008) \\
Sugarcane bagasse & MB (sulfuric acid) & $\mathrm{Cd}(\mathrm{II})$ & $38.03 \mathrm{mg} / \mathrm{g}$ & Mohan and Singh (2002) \\
Sugarcane bagasse & MB (sulfuric acid) & $\mathrm{Zn}(\mathrm{II})$ & $31.11 \mathrm{mg} / \mathrm{g}$ & Mohan and Singh (2002) \\
Sugarcane bagasse & NB & $\mathrm{Ni}(\mathrm{II})$ & $2 \mathrm{mg} / \mathrm{g}$ & Alomá et al. (2012)
\end{tabular}

$N B$ natural or unmodified biosorbent, $M B$ modified biosorbent

Table 9 Adsorption capacities of stalk materials for the removal of heavy metals from water/wastewater

\begin{tabular}{lllcl}
\hline Cellulosic materials & Type of biosorbent & Heavy metals & Adsorption capacity (mg/g) & References \\
\hline Corn stalk & AMCS (acryl nitrile) & $\mathrm{Cd}(\mathrm{II})$ & 12.73 & Zheng et al. (2010) \\
Corn stalk & MB (graft coplymerization) & $\mathrm{Cd}(\mathrm{II})$ & 21.37 & Zheng et al. (2012) \\
Sunflower stalk & NB & $\mathrm{Cu}(\mathrm{II})$ & 29.3 & Sun and Shi (1998) \\
Sunflower stalk & NB & $\mathrm{Zn}(\mathrm{II})$ & 30.73 & Sun and Shi (1998) \\
Sunflower stalk & NB & $\mathrm{Cd}(\mathrm{II})$ & 42.18 & Sun and Shi (1998) \\
Sunflower stalk & NB & $\mathrm{Cr}(\mathrm{III})$ & 25.07 & Sun and Shi (1998) \\
Sunflower stalk & NB & $\mathrm{Pb}(\mathrm{II})$ & 182.90 & Jalali and Aboulghazi. (2012) \\
Sunflower stalk & NB & $\mathrm{Cd}(\mathrm{II})$ & 69.80 & Jalali and Aboulghazi. (2013) \\
\hline
\end{tabular}

found to be 90 and $68 \%$ for NHS and AS sorbents after $90 \mathrm{~min}$ equilibrium time. The adsorption isotherm for $\mathrm{Pb}$ (II) fitted well with the Langmuir model, with binding capacities of shell of 28.18 and $8.08 \mathrm{mg} / \mathrm{g}$ for NHS and AS, respectively. Doke and Khan (2012) also used $\mathrm{H}_{2} \mathrm{SO}_{4^{-}}$ modified wood apple shell for the adsorption of $\mathrm{Cr}(\mathrm{VI})$ metal in aqueous medium. The maximum adsorption capacity was $151.51 \mathrm{mg} / \mathrm{g}$ which is the highest of other shell adsorbents. Oil palm shell was evaluated as a adsorption for the removal of $\mathrm{Cu}$ (II) from synthetic wastewater by Chong et al. 2013. An adsorption capacity of $1.756 \mathrm{mg} / \mathrm{g}$ was reported for $\mathrm{Cu}(\mathrm{II})$. They also used the same adsorbent for $\mathrm{Pb}(\mathrm{II})$ removal and reported an adsorption capacity of $3.309 \mathrm{mg} / \mathrm{g}$ for $\mathrm{Pb}(\mathrm{II})$ metal ion. The material was used for both batch mode and column mode studies. They found that the lower $\mathrm{pH}_{\mathrm{PZC}}(4.1)$ is suitable for heavy metal removal at optimum conditions. The Freundlich isotherm was fitted well than Langmuir isotherm. The kinetics of $\mathrm{Pb}(\mathrm{II})$ adsorption follow pseudosecond-order kinetic model.

\section{Leave}

Lignocellulosic materials are the structural elements of wood and other plant materials. These are present in the biosphere in abundant form. Leaves come in the category of natural materials. Most of the plants shed their leaves in unfavorable conditions and these leaves can be used as biosorbents (Table 11). The removal of $\mathrm{Cu}$ (II) from aqueous solution using dried sunflower leaves was investigated by Benaïssa and Elouchdi (2007). The influence of initial $\mathrm{Cu}(\mathrm{II})$ concentrations (10-500 mg/l), pH (5-6), contact time $(2.5-7 \mathrm{~h})$ and adsorption amount $(0.2 \mathrm{~g})$ was observed. The experimental data were well followed by Langmuir and Freundlich isotherms. The kinetic model and pseudo-first-order also supports the rate of reaction. The maximum metal ion uptake capacities obtained was $89.37 \mathrm{mg} / \mathrm{g}$. Martins et al. (2013) used castor leaf powder as bioadsorbent for the removal of $\mathrm{C}$ (II) and $\mathrm{Pb}$ (II) metals from an aqueous medium. The adsorption capacities were found to be 0.340 and $0.327 \mathrm{mmol} / \mathrm{g}$ for $\mathrm{C}$ (II) and $\mathrm{Pb}$ (II) metals, respectively.

Mondal et al. (2013) used bamboo leaf powder in the detoxification of $\mathrm{Hg}$ (II) ions from water. They used bamboo leaf powder in three forms, viz., unmodified bamboo leaf powder (BPL), modified by using anionic surfactant SDS (BLPS) and non-ionic surfactant Triton X-100 (BLPT). All these materials were characterized by BET and FTIR analysis. The experimental studies were supported by the adsorption isotherm, kinetics, thermodynamics and the mechanisms involved in it. The maximum adsorption capacity shown by unmodified, Triton 
Table 10 Adsorption capacities of shell materials for the removal of heavy metals from water/wastewater

\begin{tabular}{lllll}
\hline Cellulosic materials & Type of biosorbent & Heavy metals & Adsorption capacity (mg/g) & References \\
\hline Almond shell & $\mathrm{NB}$ & $\mathrm{Pb}(\mathrm{II})$ & 8.08 & Pehlivan et al. (2009a, b, c) \\
Bael fruit shell & $\mathrm{NB}$ & $\mathrm{Cr}(\mathrm{VI})$ & 17.27 & Anandkumar and Mandal (2009) \\
Cashew nut shell & $\mathrm{NB}$ & $\mathrm{Cd}(\mathrm{II})$ & 22.11 & Kumar et al. (2012a, b) \\
Chestnut shell & $\mathrm{NB}$ & $\mathrm{Cu}(\mathrm{II})$ & 12.56 & Babel and Kurniawan (2004) \\
Hazelnut shell & $\mathrm{NB}$ & $\mathrm{Pb}(\mathrm{II})$ & 28.18 & Babel and Kurniawan (2004) \\
Hazelnut shell & $\mathrm{NB}$ & $\mathrm{PB}(\mathrm{II})$ & 28.18 & Pehlivan et al. (2009a, b, c) \\
Palm shell & $\mathrm{MB}($ tomatoes $)$ & $\mathrm{Cu}(\mathrm{II})$ & 83.33 & Ismaiel et al. (2013) \\
Oil palm shell & $\mathrm{NB}$ & $\mathrm{Pb}(\mathrm{II})$ & 1.75 & Chong et al. (2013) \\
Oil palm shell & $\mathrm{NB}$ & $\mathrm{Cu}(\mathrm{II})$ & 9.39 & Chong et al. (2013) \\
Lentil & $\mathrm{NB}$ & $\mathrm{Cu}(\mathrm{II})$ & 2.59 & Aydm et al. (2008) \\
Rice & $\mathrm{NB}$ & $\mathrm{Cr}(\mathrm{VI})$ & 200 & Aydin et al. (2008) \\
Walnut shell & $\mathrm{MB}\left(\mathrm{H}_{2} \mathrm{SO}_{4}\right)$ & $\mathrm{Cu}(\mathrm{II})$ & 17.42 & Kumar et al. (2012a, b) \\
Wheat & $\mathrm{NB}$ & $\mathrm{Cr}(\mathrm{VI})$ & 151.51 & Aydm et al. (2008) \\
Wood apple shell & $\mathrm{MB}\left(\mathrm{H}_{2} \mathrm{SO}_{4}\right)$ & & Doke and Khan (2012) \\
\hline
\end{tabular}

$N B$ natural or unmodified biosorbent, $M B$ modified biosorbent

Table 11 Adsorption capacities of leave materials for the removal of heavy metals from water/wastewater

\begin{tabular}{lllll}
\hline Cellulosic materials & Type of biosorbent & Heavy metals & Adsorption capacity & References \\
\hline Bamboo leaf powder & NB & $\mathrm{Hg}(\mathrm{II})$ & $27.11 \mathrm{mg} / \mathrm{g}$ & Mondal et al. (2013) \\
Bamboo leaf powder & MB (anionic surfactant SDS) & $\mathrm{Hg}(\mathrm{II})$ & $28.1 \mathrm{mg} / \mathrm{g}$ & Mondal et al. (2013) \\
Bamboo leaf powder & MB (Triton X-100) & $\mathrm{Hg}(\mathrm{II})$ & $31.05 \mathrm{mg} / \mathrm{g}$ & Mondal et al. (2013) \\
Castor leaves & $\mathrm{NB}$ & $\mathrm{Pb}(\mathrm{II})$ & $0.327 \mathrm{mmol} \mathrm{g/l}$ & Martins et al. (2013) \\
Castor leaves & $\mathrm{NB}$ & $\mathrm{Cd}(\mathrm{II})$ & $0.340 \mathrm{mmol} \mathrm{g/l}$ & Martins et al. (2013) \\
Neem leaves & $\mathrm{MB}(\mathrm{HCl})$ & $\mathrm{Cr}(\mathrm{VI})$ & $62.97 \mathrm{mg} / \mathrm{g}$ & Babu and Gupta (2008) \\
Pine leaf powder & $\mathrm{NB}$ & $\mathrm{As}(\mathrm{V})$ & $3.27 \mathrm{mg} / \mathrm{g}$ & Shafique et al. (2012) \\
Sunflower leaves & $\mathrm{NB}$ & $\mathrm{Cu}(\mathrm{II})$ & $89.37 \mathrm{mg} / \mathrm{g}$ & Benaïssa and Elouchdi (2007) \\
\hline
\end{tabular}

$N B$ natural or unmodified biosorbent, $M B$ modified biosorbent

X-modified and SDS-modified BPL was 27.11, 28.1 and $35.05 \mathrm{mg} / \mathrm{g}$, respectively. Very little literature investigation has been done on the use of pine needles (or leaf) in heavy metal removal. Pine needle is novel emerging adsorbent which was examined by Shafique et al. (2012) used chir pine leaves (Pinus roxburghii) in the removal of $\mathrm{As}(\mathrm{V})$ ions from aqueous solution. The maximum adsorption was reported at $\mathrm{pH} 4.0$ and equilibrium was achieved in $35 \mathrm{~min}$. The pine leaves were tested for various contact times, $\mathrm{pH}$, agitation speed and initial metal concentration to evaluate the optimum conditions which showed the maximum $\mathrm{As}(\mathrm{V})$ metal ions uptake of $3.27 \mathrm{mg} / \mathrm{g}$. The experiment was further supported by pseudo-second-order kinetics.

\section{Bark}

Plant's bark is also used for heavy metal removal in aqueous solution (Table 12). Different concentrations of $\mathrm{Cr}(\mathrm{VI})$ and Cr(III) ions were studied by Sarin and Pant 2006. They used eucalyptus bark in the removal of $\mathrm{Cr}(\mathrm{VI})$ and $\mathrm{Cr}(\mathrm{III})$ metal ions. The experimetal study was performed in a batch process and the influence of the following parameters, $\mathrm{pH}$, contact time and initial concentration, will be investigated. The adsorption was followed by Fruendlich isotherms mainly and first-order Lagergren kinetics. The adsorption capacity was found to be $45 \mathrm{mg} / \mathrm{g}$ at $\mathrm{pH} 2$.

Alkali $\mathrm{NaOH}$ - and acid $\mathrm{H}_{2} \mathrm{SO}_{4}$-pretreated neem barks were used as adsorbent and the influence of initial cation 
concentration, temperature and $\mathrm{pH}$ was investigated to optimize $\mathrm{Zn}$ (II) and $\mathrm{Cd}(\mathrm{II})$ metal ion removal from aqueous solutions (Naiya et al. 2009). The maximum adsorption capacity was obtained as 13.29 for $\mathrm{Zn}$ (II) ion and $25.57 \mathrm{mg} / \mathrm{g}$ for $\mathrm{Cd}(\mathrm{II})$ ion at $\mathrm{pH} 5$ for $\mathrm{Zn}(\mathrm{II})$ and 6 for $\mathrm{Cd}(\mathrm{II})$, respectively. Different parameters such as $\mathrm{pH}$, initial ion concentration, contact time and adsorbent doses were studied to evaluate the equilibrium conditions. Thermodynamic parameters and Gibbs free energy $(\Delta \mathrm{G})$ values for $\mathrm{Zn}(\mathrm{II})$ are $-4.76 \mathrm{KJmol}^{-1}$ and for $\mathrm{Cd}(\mathrm{II})$ are $-6.09 \mathrm{KJmol}^{-1}$, respectively, were also studied. Reddy et al. (2011) also used Moringa oleifera bark as low-cost adsorbents for the biosorption of $\mathrm{Ni}$ (II) metal from aqueous solution. The adsorption capacity was found to be $30.38 \mathrm{mg} / \mathrm{g}$ at $6 \mathrm{pH}$.

\section{Fiber}

In 2010, the removal of heavy metals from wastewater by using Agave Americana fibers was studied by Hamissa et al. 2010. It was indicated that Agave Americana fiber is more effective for $\mathrm{Pb}(\mathrm{II})$ and $\mathrm{Cd}(\mathrm{II})$ is also exchanged at a satisfactory level. Approximately, $40.0 \mathrm{mg} / \mathrm{g}$ of $\mathrm{Pb}(\mathrm{II})$ and $12.5 \mathrm{mg} / \mathrm{g}$ of $\mathrm{Cd}(\mathrm{II})$ were removed. The equilibrium conditions were obtained at $20{ }^{\circ} \mathrm{C}$ temperature, $\mathrm{pH}$ 5.0, contact time of $30-60 \mathrm{~min}$ and $5 \mathrm{~g} / 1$ biomass adsorbent media. Infrared scopy revealed that the functional groups were involved in $\mathrm{Pb}$ (II) and $\mathrm{Cd}(\mathrm{II})$ ion bins on adsorbent media. Scanning electron microscopy (SEM) also gives proof of the adsorption surface area. Thermodynamic parameters such as enthalpy change $\left(\Delta \mathrm{H}^{\mathrm{o}}\right)$, free energy change $\left(\Delta \mathrm{G}^{\mathrm{o}}\right)$ and entropy change $\left(\Delta S^{\circ}\right)$ were calculated from Langmuir and Freundlich isotherm constant. The positive value of $\Delta H^{\mathrm{o}}$ indicates that the sorption process is endothermic in nature. Hydrogen peroxide-modified coir was also used in metal removal from aqueous solutions. It was found that coir fibers with chemical modification were found to be more effective than unmodified coir fibers. Heavy metals such as $\mathrm{Ni}(\mathrm{II}), \mathrm{Zn}$ (II) and $\mathrm{Fe}(\mathrm{II})$ could be eliminated with a removal capacity of $4.33,7.88$ and $7.49 \mathrm{mg} / \mathrm{g}$ for chemically modified adsorbents, respectively, and unmodified coir fiber uptake capacity were $2.51,1.53$ and $2.84 \mathrm{mg} / \mathrm{g}$. It was also found that metal capacity decreases with lowering of $\mathrm{pH}$. Desorption study was also carried with dilution of $\mathrm{NaOH}$ solution with loaded metal ions (Shukla et al. 2006). It was reported the adsorption process decreased with lowering of $\mathrm{pH}$ and the Langmuir model fitted for modified jute fibers. Plant fibers such as those of Agave americana, kenaf, coir, banana, remie and jute were used for heavy metal removal (Table 13).

In 2005, the use of modified jute fibers to remove heavy metals was investigated (Shukla and Pai 2005). It was observed that modified jute fibers were used in the synthetic waste water containing toxic heavy metals, viz., $\mathrm{Cu}(\mathrm{II}), \mathrm{Ni}(\mathrm{II})$ and $\mathrm{Zn}$ (II). They used two types of fibers in the metal ion sequestration. The dye-loaded jute fibers showed the metal uptake value of $8.4,5.26$ and $5.95 \mathrm{mg} / \mathrm{g}$ for $\mathrm{Cu}(\mathrm{II}), \mathrm{Ni}(\mathrm{II})$ and $\mathrm{Zn}(\mathrm{II})$, respectively. The other adsorbent modified with hydrogen peroxide showed the metal uptake values of $7.73,3.37$ and $3.55 \mathrm{mg} / \mathrm{g}$ for unmodified jute fibers.

\section{Fruit stone/waste}

Fruit containing stones (stone fruit) are used adsorbent for metal removal after removing their central fleshy parts. Peach stones, olive stones and palm fruit bunches' inner and outer hard parts are used as adsorbents for metal removal. The raw material obtained from the fruit stone part is dried and washed with organic solvents (Ali 2014). Rashed (2006) carried out a comparative study of fruit stones (peach and apricot) and found their adsorption potential. The equilibrium time for lead adsorption was 3-5 h (\% Pb adsorption $93 \%$ for apricot and $97.64 \%$ for peach). The lead adsorption onto peach stone was found to be higher than onto stone up to $3.36 \%$ at $3 \mathrm{~h}$. The

Table 12 Adsorption capacities of bark materials for the removal of heavy metals from water/wastewater

\begin{tabular}{lllll}
\hline Cellulosic materials & Type of biosorbents & Heavy metals & Adsorption capacity (mg/g) & References \\
\hline Acacia leucocephala & $\mathrm{NB}$ & $\mathrm{Cu}(\mathrm{II})$ & 147.1 & Munagapati et al. (2010) \\
Acacia leucocephala & $\mathrm{NB}$ & $\mathrm{Cd}(\mathrm{II})$ & 167.7 & Munagapati et al. (2010) \\
Acacia leucocephala & $\mathrm{NB}$ & $\mathrm{Pb}(\mathrm{II})$ & 185.2 & Munagapati et al. (2010) \\
Moringa oleifera & $\mathrm{NB}$ & $\mathrm{Ni}(\mathrm{II})$ & 30.38 & Reddy et al. (2011) \\
Moringa oleifera & $\mathrm{NB}$ & $\mathrm{Pb}(\mathrm{II})$ & 34.6 & Reddy et al. (2010) \\
Neem bark & $\mathrm{NB}$ & $\mathrm{Zn}(\mathrm{II})$ & 13.29 & Naiya et al. (2009) \\
Neem bark & $\mathrm{NB}$ & $\mathrm{Cd}(\mathrm{II})$ & 25.57 & Naiya et al. (2009) \\
\hline
\end{tabular}

$N B$ natural or unmodified biosorbent, $M B$ modified biosorbent 
Table 13 Adsorption capacities of fiber materials for the removal of heavy metals from water/wastewater

\begin{tabular}{|c|c|c|c|c|}
\hline Cellulosic materials & Type of biosorbent & Heavy metals & Adsorption capacity (mg/g) & References \\
\hline \multirow[t]{2}{*}{ Agave americana } & NB & $\mathrm{Pb}(\mathrm{II})$ & 39.7 & Hamissa et al. (2010) \\
\hline & NB & $\mathrm{Cd}(\mathrm{II})$ & 12.5 & Hamissa et al. (2010) \\
\hline \multirow[t]{6}{*}{ Coir fibers } & NB & $\mathrm{Ni}(\mathrm{II})$ & 2.51 & Shukla et al. (2006) \\
\hline & NB & $\mathrm{Zn}(\mathrm{II})$ & 1.53 & Shukla et al. (2006) \\
\hline & NB & $\mathrm{Fe}(\mathrm{II})$ & 2.84 & Shukla et al. (2006) \\
\hline & $\mathrm{MB}\left(\mathrm{H}_{2} \mathrm{O}_{2}\right)$ & $\mathrm{Ni}(\mathrm{II})$ & 4.33 & Shukla et al. (2006) \\
\hline & $\mathrm{MB}\left(\mathrm{H}_{2} \mathrm{O}_{2}\right)$ & $\mathrm{Zn}(\mathrm{II})$ & 7.88 & Shukla et al. (2006) \\
\hline & $\mathrm{MB}\left(\mathrm{H}_{2} \mathrm{O}_{2}\right)$ & $\mathrm{Fe}(\mathrm{II})$ & 7.49 & Shukla et al. (2006) \\
\hline Hemp fibers & $\mathrm{NB}$ & $\mathrm{Co}(\mathrm{II})$ & 13.58 & Tofan et al. (2013) \\
\hline \multirow[t]{9}{*}{ Jute fibers } & NB & $\mathrm{Cu}(\mathrm{II})$ & 4.23 & Shukla and Pai (2005) \\
\hline & NB & $\mathrm{Ni}(\mathrm{II})$ & 3.37 & Shukla and Pai (2005) \\
\hline & NB & $\mathrm{Zn}(\mathrm{II})$ & 3.55 & Shukla and Pai (2005) \\
\hline & $\mathrm{MB}\left(\mathrm{H}_{2} \mathrm{O}_{2}\right)$ & $\mathrm{Cu}(\mathrm{II})$ & 7.73 & Shukla and Pai (2005) \\
\hline & $\mathrm{MB}\left(\mathrm{H}_{2} \mathrm{O}_{2}\right)$ & $\mathrm{Ni}(\mathrm{II})$ & 5.57 & Shukla and Pai (2005) \\
\hline & $\mathrm{MB}\left(\mathrm{H}_{2} \mathrm{O}_{2}\right)$ & $\mathrm{Zn}(\mathrm{II})$ & 8.02 & Shukla and Pai (2005) \\
\hline & CB (dye loaded) & $\mathrm{Cu}(\mathrm{II})$ & 8.4 & Shukla and Pai (2005) \\
\hline & CB (dye loaded) & $\mathrm{Ni}(\mathrm{II})$ & 5.26 & Shukla and Pai (2005) \\
\hline & CB (dye loaded) & $\mathrm{Zn}(\mathrm{II})$ & 5.95 & Shukla and Pai (2005) \\
\hline
\end{tabular}

$N B$ natural or unmodified biosorbent, $M B$ modified biosorbent

suitable $\mathrm{pH}$ was observed to be $7-8$. The heavy metal removal capacities of fruit stone/waste are shown in Table 14.

Alslaibi et al. (2013) determined the potential of microwaved olive stone-activated carbon (OSAC) for removal of cadmium metal ion. The maximum cadmium uptake obtained using OSAC was $95.32 \%$. The adsorption process was followed by Langmuir isotherm with $11.72 \mathrm{mg} / \mathrm{g}$ adsorption capacity. Mohammadi et al. (2010) examined the efficacy of modified sea-buckthorn stone to adsorb $\mathrm{Pb}(\mathrm{II})$ metal ions. Activated carbons have been prepared using phosphoric acid and zinc chloride chemical activation. The maximum adsorption of $\mathrm{Pb}$ (II) on activated carbon was $51.81 \mathrm{mg} / \mathrm{g}$ with $\mathrm{H}_{3} \mathrm{PO}_{4}$ and $25.91 \mathrm{mg} / \mathrm{g}$ with activated $\mathrm{ZnCl}_{2}$.

\section{Peat}

Peat moss is used as an inexpensive and naturally available low-cost adsorbent. Lignin and cellulose are the chief components of peat. Due to having polar functional groups, peat works effectively in metal detoxification from aqueous solutions. Ho and Mckay (2004) investigated sorption of $\mathrm{Cu}$ (II) by peat moss. The adsorption was maximum at $\mathrm{pH}$ 5 , and the maximum adsorption capacity was $0.199 \mathrm{mmol} /$ $\mathrm{g}$ at $20^{\circ} \mathrm{C}$. The mechanism behind $\mathrm{Cu}$ (II) uptake was cation exchange. The cupper ion was exchanged with hydrogen ions in the presence of humic and fulvic acids. Gupta et al. (2009) described adsorption of $\mathrm{Cu}$ and $\mathrm{Ni}$ ions onto Irish peat moss. The adsorption of $\mathrm{Cu}(\mathrm{II})$ and $\mathrm{Ni}$ (II) from aqueous solutions on peat moss was studied over a range of $2-8(\mathrm{pH})$ and $5-100 \mathrm{mg} / \mathrm{l}$ (concentration). The maximum biosorption capacity of Iris peat moss was found to be $17.6 \mathrm{mg} / \mathrm{g}$ for $\mathrm{Cu}$ (II) and $14.5 \mathrm{mg} / \mathrm{g}$ for Liu et al. (2009) studied the use of peat for removal of nickel from aqueous solutions at different $\mathrm{pH}$ values. It was observed that metal ion removal increases with increase in $\mathrm{pH}$ value. The first-order model favored the experimental data. Table 15 represents the metal removal capacities of different types of peat biomass.

Janaki et al. (2015) reported the removal of $\mathrm{Ni}(\mathrm{II})$ ions from an aqueous solution of Indian peat moss (sphagnum) as adsorbent. The effects of $\mathrm{pH}$, adsorbent dosage and initial concentrations were studied in batch experiment. The experimental results revealed that $99.5 \%$ of $\mathrm{Ni}(\mathrm{II})$ ion removal occurs at $\mathrm{pH} 6$. The authors also described the interaction between the metal ions and peat mosses by Fourier transform infrared spectroscopy.

\section{Vegetable waste}

The applicability of vegetable waste as low-cost adsorbent leads to zero waste discharge in the environment. Vegetable wastes are easily available and have no 
Table 14 Adsorption capacities of fruit stone for the removal of heavy metals from water/wastewater

\begin{tabular}{lllll}
\hline Cellulosic materials & Type of biosorbent & Heavy metals & Adsorption capacity (mg/g) & References \\
\hline Apricot stone & $\mathrm{MB}\left(\mathrm{H}_{3} \mathrm{PO}_{4}\right)$ & $\mathrm{Pb}(\mathrm{II})$ & 111.11 & Abbas et al. (2014) \\
Date pit & $\mathrm{NB}$ & $\mathrm{Cu}(\mathrm{II})$ & 35.9 & Mohammad et al. (2010) \\
Date pit & $\mathrm{NB}$ & $\mathrm{Cd}(\mathrm{II})$ & 39.5 & Mohammad et al. (2010) \\
Olive stone & $\mathrm{NB}$ & $\mathrm{Pb}(\mathrm{II})$ & 92.6 & Fiol et al. (2006) \\
Peanut hull & $\mathrm{NB}$ & $\mathrm{Cu}(\mathrm{II})$ & 21.25 & Zhu et al. (2009) \\
\hline
\end{tabular}

$N B$ natural or unmodified biosorbent, $M B$ modified biosorbent

Table 15 Adsorption capacities of peat for the removal of heavy metals from water/wastewater

\begin{tabular}{lllll}
\hline Cellulosic materials & Type of biosorbent & Heavy metals & Adsorption capacity (mg/g) & References \\
\hline Peat & MB (thermal activated) & $\mathrm{Pb}(\mathrm{II})$ & 81.3 & Lee et al. (2015) \\
Peat & $\mathrm{MB}$ (thermal activated) & $\mathrm{Cu}(\mathrm{II})$ & 18.2 & Lee et al. (2015) \\
Peat & $\mathrm{MB}$ (thermal activated) & $\mathrm{Cd}(\mathrm{II})$ & 39.8 & Lee et al. (2015) \\
Peat & $\mathrm{MB}(\mathrm{NaCl})$ & $\mathrm{Cr}(\mathrm{III})$ & 18.75 & Henryk et al. (2016) \\
Peat & $\mathrm{MB}(\mathrm{NaCl})$ & $\mathrm{Cr}(\mathrm{VI})$ & 8.02 & Henryk et al. (2016) \\
Sphagnum peat moss & $\mathrm{MB}$ (thermally activated) & $\mathrm{Cu}(\mathrm{II})$ & 12.6 & Ho and Mckay (2004)
\end{tabular}

$N B$ natural or unmodified biosorbent, $M B$ modified biosorbent

economic use (Table 16). Gill et al. (2013) reported the removal of $\mathrm{Ni}(\mathrm{II})$ onto a mixture of vegetable waste as adsorbent. The mixture of vegetable waste was prepared in the ratio of 1:1 (potato:carrot peels). The effects of various operating variables, viz., initial $\mathrm{pH}$, temperature, contact time, initial metal concentration and biosorbent dose, were studied. The maximum adsorption of nickel (79.32 \%) was found with $75 \mathrm{~min}$ of contact time and $3.0 \mathrm{~g}$ of biosorbent at $35{ }^{\circ} \mathrm{C}$ and ph 4 . FTIR spectrophotometer and X-ray flourescence spectrophotometer techniques confirm the adsorption process. Bhatti et al. (2010) studied the adsorption of chromium on Daucus carota L. waste biomass. The maximum removal capacity for $\mathrm{Cr}(\mathrm{III})$ and $\mathrm{Cr}(\mathrm{VI})$ was 85.65 and $88.27 \mathrm{mg} / \mathrm{g}$, respectively. The maximum removal rate occurred at biosorbent dose $0.1 \mathrm{~g}$, biosorbent size $0.250 \mathrm{~mm}$, initial concentration $100 \mathrm{mg} / \mathrm{l}$, temperature $30{ }^{\circ} \mathrm{C}$ and contact time $240 \mathrm{~min}$.

Aksu and Isoglu (2005) examined the biosorption equilibria and kinetics of copper(II) metal ion via agricultural waste sugar beet pulp. The highest biosorption capacity was $28.5 \mathrm{mg} / \mathrm{g}$ for $\mathrm{Cu}(\mathrm{II})$ at $25{ }^{\circ} \mathrm{C}$ and initial $\mathrm{pH}$ value 4. The biosorption rates were found to follow pseudo-first order and pseudo-second order.

\section{Grass}

Grass is considered to be of low cost and abundant because of mowing lawns, gardens, parks and open fields
(Table 17). Grasses are major organic components of solid waste and comprise about $14.6 \%$ of total municipal solid waste (MSW) and about $50 \%$ organic content of the MSW (Yu et al. 2002). Koroki et al. (2010) used culm of bamboo grass treated with concentrated sulfuric acid for $\mathrm{Cr}(\mathrm{V})$ metal ion removal from aqueous solutions. They found that the $\mathrm{Cr}(\mathrm{VI})$ requestration was highly correlated with $\mathrm{pH}$ and favored physicochemical sorption mechanism. The $\mathrm{Cr}(\mathrm{VI})$ sorption was observed irreversible due to strong bonding of $\mathrm{HCrO}_{4}^{-}$and the presence of active sites. Zuo et al. (2012) tried to evaluate the applicability of sodium hydroxide solution $(\mathrm{NaOH})$ immersed lemon grass (ILG) for the removal of cupper(Cu), zinc( $\mathrm{Zn}$ ) and cadmium $(\mathrm{Cd})$ from single and multi-metal solutions. According to the authors, maximum removal was $13.93 \mathrm{mg} \mathrm{Cu}$, $15.87 \mathrm{mg} \mathrm{Zn}$ and $39.53 \mathrm{mg}$ Cd per gram ILG. FTIR studies showed that $\mathrm{NaOH}$ modification leads to increase in the number of sorption sites for metal uptake.

Pandey et al. (2015) explored NaOH-treated kush grass leaves and bamboo leaves for $\mathrm{Cd}(\mathrm{II})$ removal from aqueous media. NaOH-modified Desmostachya bipinnata, Kush grass leaves (MDBL) and Bambusa arundinacea (bamboo) leaves (MBAL) were used in batch experiments. Langmuir isotherm fitted well than Freundlich isotherm and the maximum adsorption capacity was found to be $15.22 \mathrm{mg} / \mathrm{g}$ for MBDL and $19.70 \mathrm{mg} / \mathrm{g}$ for MBAL at room temperature. Desorption studies were also carried out using $0.1 \mathrm{~N}$ $\mathrm{HNO}_{3} ; 94.18$ and $92.98 \%$ recovery of metals was obtained 
Table 16 Adsorption capacities of vegetable waste for the removal of heavy metals from water/wastewater

\begin{tabular}{lllcl}
\hline Cellulosic materials & Type of biosorbent & Heavy metals & Adsorption capacity (mg/g) & References \\
\hline Cabbage waste & $\mathrm{NB}$ & $\mathrm{Pb}(\mathrm{II})$ & 60.57 & Hossain et al. (2014) \\
Cabbage waste & $\mathrm{NB}$ & $\mathrm{Cd}(\mathrm{II})$ & 20.57 & Hossain et al. (2014) \\
Cassava peelings & $\mathrm{MB}$ (mercapto acetic acid) & $\mathrm{Cu}(\mathrm{II})$ & 127.3 & Horsfall et al. (2004) \\
Cassava peelings & $\mathrm{NB}$ & $\mathrm{Cd}(\mathrm{II})$ & 119.6 & Horsfall et al. (2004) \\
Cauliflower waste & $\mathrm{NB}$ & $\mathrm{Pb}(\mathrm{II})$ & 47.63 & Hossain et al. (2014) \\
Cauliflower waste & $\mathrm{NB}$ & $\mathrm{Cd}(\mathrm{II})$ & 21.32 & Hossain et al. (2014) \\
Fluted pumpkin seed shell & $\mathrm{MB}\left(\mathrm{H}_{3} \mathrm{PO}_{4}\right)$ & $\mathrm{Pb}(\mathrm{II})$ & 14.286 & Okoye et al. (2010) \\
Potato peel & $\mathrm{Mb}$ (thermally activated) & $\mathrm{Cu}(\mathrm{II})$ & 84.74 & Guechi and Hamdaowio (2015)
\end{tabular}

$N B$ natural or unmodified biosorbent, $M B$ modified biosorbent

Table 17 Adsorption capacities of grass for the removal of heavy metals from water/wastewater

\begin{tabular}{lllll}
\hline Cellulosic materials & Type of biosorbent & Heavy metals & Adsorption capacity (mg/g) & References \\
\hline Alfa grass & $\mathrm{MB}\left(\mathrm{H}_{2} \mathrm{SO}_{4}\right)$ & $\mathrm{Cr}(\mathrm{VI})$ & 75.8 & Tazrouti and Amrani (2009)
\end{tabular}

$N B$ natural or unmodified biosorbent, $M B$ modified biosorbent

for Cd(II) ions from MDBL and MBL, respectively. Hossain et al. (2012) utilized garden grass (GG) for removal of copper(II) from aqueous solutions. The maximum adsorption and desorption capacities were 58.34 and $319.03 \mathrm{mg} /$ $\mathrm{g}$, respectively, for $1 \mathrm{~g}$ dose. From the results, it was revealed that GG occupied high surface area and functional groups on the surface area.

\section{Cake}

The cakes of olive, cotton seed and jatropha are agricultural wastes and applied as cellulosic adsorbents for heavy metal removal (Table 18). Malathi et al. (2015) examined the ability of activated carbon prepared from sulfuric acidtreated cottonseed cake (SCSC) by chemical activation. According to the authors, the equilibrium time and optimum $\mathrm{pH}$ range were observed to be $3 \mathrm{~h}$ and 4.0-6.0, respectively. SCSC exhibit a higher adsorption capacity of $115.86 \mathrm{mg} / \mathrm{g}$ than commercial activated carbon $(21.69 \mathrm{mg} /$ g) at $300 \mathrm{~K}$. Bose et al. (2011) evaluated a biodiesel waste of jatropha seed press cake (JPC) for the elimination of hexavalent chromium ion from aqueous solutions. The chromium metal removal increases with increase in $\mathrm{pH}$ as well as concentration. The peak biosorption capacity was observed at $22.727 \mathrm{mg}$ of $\mathrm{Cr}(\mathrm{VI}) / \mathrm{g}$ of biosorbent at $30^{\circ} \mathrm{C}$. The activation energy for the adsorption process was $27.114 \mathrm{~kJ} / \mathrm{mol}$, showing a physical process.

Konstantinou et al. (2007) investigated the sorption ability of olive cake for $\mathrm{Cu}$ (II) and $\mathrm{Eu}(\mathrm{II})$ ions in a batch study. They observed that the sorption process takes place due to formation of an inner-sphere complex with active sites of the surface. Elouear et al. (2008) studied the removal of toxic metal ions from aqueous solutions using exhausted olive cake ash (EOCA). The optimum removal occurred up to $2 \mathrm{~h}$ contact time for $\mathrm{Ni}$ (II) and $\mathrm{Cd}$ (II) onto EOCA at $\mathrm{pH}$ 6. Langmuir isotherm correlated well than Freundlich isotherm. The adsorption capacities were 8.34 and $7.32 \mathrm{mg} / \mathrm{g}$ for $\mathrm{Ni}(\mathrm{II})$ and $\mathrm{Cd}(\mathrm{II})$, respectively. Khan et al. (2012) utilized oil cake in the removal of nickel from aqueous medium. Metal removal favored pseudo-second order model. The breakthrough capacities for 5 and $10 \mathrm{mg} /$ 1 were 0.25 and $4.5 \mathrm{mg} / \mathrm{g}$ and exhausted capacities for 5 and $10 \mathrm{mg} / \mathrm{l}$ were 4.5 and $9.5 \mathrm{mg} / \mathrm{g}$ for $\mathrm{Ni}(\mathrm{II})$ metal ion, respectively.

\section{Others adsorbents}

Different cellulosic material used in the removal of heavy metals such as cactus cladodes, castor seed hull, Eichhornia crassipes roots, hemp fibers, meranti wood and Prosopis juliflora seed were found to be efficient as low-cost bioadsorbents (Table 19).

\section{Conclusion}

Adsorption is an efficient technique in heavy metal removal rather than coagulation, flocculation, ion exchange, precipitation, osmosis and flotation. These conventional techniques are not suitable for the removal of heavy metal ions from wastewater at trace concentrations. The use of commercially activated carbons for wastewater 
Table 18 Adsorption capacities of cake for the removal of heavy metals from water/wastewater

\begin{tabular}{lllll}
\hline Cellulosic materials & Type of biosorbent & Heavy metals & Adsorption capacity $(\mathrm{mg} / \mathrm{g})$ & References \\
\hline Gingelly oil cake & $\mathrm{MB}$ (thermal activated) & $\mathrm{Pb}(\mathrm{II})$ & 105.26 & Nagashanmugam and Srinivasan (2010) \\
Gingelly oil cake & $\mathrm{MB}\left(\mathrm{H}_{2} \mathrm{SO}_{4}\right)$ & $\mathrm{Pb}(\mathrm{II})$ & 114.94 & Nagashanmugam and Srinivasan (2010) \\
Moringa seed cake & $\mathrm{MB}(n$-hexane) & $\mathrm{Cr}(\mathrm{VI})$ & 3.191 & Meneghel et al. (2013) \\
Soya cake & $\mathrm{NB}$ & $\mathrm{Cr}(\mathrm{VI})$ & 0.288 & Daneshwar et al. (2002)
\end{tabular}

$N B$ natural or unmodified biosorbent, $M B$ modified biosorbent

Table 19 Adsorption capacities of different cellulosic materials for the removal of heavy metals from water/wastewater

\begin{tabular}{lllcl}
\hline Cellulosic materials & Type of biosorbent & Heavy metals & Adsorption capacity (mg/g) & References \\
\hline Cactus cladodes & $\mathrm{MB}$ & $\mathrm{Cd}(\mathrm{II})$ & 30.42 & Barka et al. (2013) \\
Cactus cladodes & $\mathrm{MB}$ & $\mathrm{Pb}(\mathrm{II})$ & 98.62 & Barka et al. (2013) \\
Castor seed hull & $\mathrm{MB}$ & $\mathrm{Zn}(\mathrm{II})$ & 6.72 & Mohammod et al. (2011) \\
Coir pith & $\mathrm{MB}$ & $\mathrm{Co}(\mathrm{II})$ & 12.82 & Parab et al. (2006) \\
& $\mathrm{MB}$ & $\mathrm{Cr}(\mathrm{II})$ & 11.56 & Parab et al. (2006) \\
& $\mathrm{MB}(\mathrm{II})$ & 15.95 & Parab et al. (2006) \\
Eichhornia crassipes root & $\mathrm{MB}$ & $\mathrm{Cu}(\mathrm{II})$ & 32.51 & Li et al. (2010) \\
Eichhornia crassipes root & $\mathrm{MB}$ & $\mathrm{Cr}(\mathrm{III})$ & 33.98 & Li et al. (2010) \\
Meranti wood & $\mathrm{MB}$ & $\mathrm{Cd}(\mathrm{II})$ & 175.43 & Rafatullah et al. (2012) \\
Prosopis juliflora seed & $\mathrm{MB}$ & 40.32 & Jayaram and Prasad (2009) \\
\hline
\end{tabular}

$N B$ natural or unmodified biosorbent, $M B$ modified biosorbent

treatment leads to increase in the cost of treatment, and, hence, researchers are focusing on the use of feasible cellulosic low-cost adsorbents for metal adsorption. Cellulosic waste materials are promising adsorbents for wastewater treatments, because of their abundance and renewability. Most of these cellulosic wastes are rich in cellulose, hemicelluloses and lignin content which adhere to toxic pollutants on the surface. In this review, the emerging cellulosic low-cost adsorbents are utilized for the removal of various kinds of metals from different types of aqueous solutions. It is evident that most of the cellulosic adsorbents applied for metal sequestration exhibited efficient adsorption capacity. So, these materials can serve as an alternative to commercially available activated carbons. Further research requires investigation of structural studies of adsorbents, multi-metal studies, immobilization of adsorbent, reuse of adsorbent, recovery of metals and pilotscale studies.

Open Access This article is distributed under the terms of the Creative Commons Attribution 4.0 International License (http:// creativecommons.org/licenses/by/4.0/), which permits unrestricted use, distribution, and reproduction in any medium, provided you give appropriate credit to the original author(s) and the source, provide a link to the Creative Commons license, and indicate if changes were made.

\section{References}

Abbas M, Kaddour S, Trari M (2014) Kinetic and equilibrium studies of cobalt adsorption on apricot stone activated carbon. J Ind Eng Eng Chem 20(3):745-751

Abbasi T, Abbasi SA (2010) Biomass energy and the environmental impacts associated with its production and utilization. Renew Sustain Energy Rev 14:919-937

Adebowale KO, Unuabonah IE, Olu-Owolabi BI (2006) The effect of some operating variables on the adsorption of lead and cadmium ions on kaolinite clay. J Hazard Mater 134:130-139

Ahmad AL, Ooi BS (2010) A study on acid reclamation and copper recovery using low pressure nanofiltration membrane. Chem Eng J 56:257-263

Ajmal M, Khan AH, Ahmad S, Ahmad A (1998) Role of sawdust in the removal of copper (II) from industrial wastes. Water Res 22:3085-3091

Ajmal M, Rao RAK, Ahmad R, Ahmad J (2000) Adsorption studies on Citrus reticulate (fruit peel of orange): removal and recovery of $\mathrm{Ni}(\mathrm{II})$ from electroplating wastewater. J Hazard Mater 79:117-131

Ajmal M, Rao RAK, Anwar S, Ahmad J, Ahmad R (2003) Adsorption studies on rice husk: removal and recovery of $\mathrm{Cd}(\mathrm{II})$ from wastewater. Bioresour Technol 86(2):147-149

Ajmal M, Rao RAK, Ahmad R, Khan MA (2006) Adsorption studies on Parthenium hysterophrous weed: removal and recovery of $\mathrm{Cd}$ (II) from wastewater. J Hazard Mater B135:242-248

Aksu Z, Isoglu IA (2005) Removal of copper(II) ions from aqueous solution by biosorption onto agricultural waste sugar beet pulp. Process Biochem 40(9):3031-3044 
Ali I (2014) The quest for active carbon adsorbent substituted: inexpensive adsorbent for toxic metal ions removal from wastewater. Sep Purif Rev 39(3-4):97-171

Al-Jlil SA, Alsewailem FD (2009) Saudi Arabian clays for lead removal in wastewater. Appl Clay Sci 42:671-674

Alomá I, Martín-Lara MA, Rodríguez IL, Blázquez G, Calero M (2012) Removal of nickel (II) ions from aqueous solutions by biosorption on sugarcane bagasse. J Taiwan Inst Chem E 43:275-281

AL-Othman ZA, Ali R, Naushad MU (2012) Hexavalent chromium removal from aqueous medium by activated carbon prepared from peanut shell:Adsorption kinetics, equilibrium and thermodynamic studies. Chem Eng J 184:238-247

Al-Rashdi B, Samerfield C, Hilal N (2011) Heavy metals removal using adsorption and nanofiltration techniques. Sep Purif Rev 40:209-259

Alslaibi TM, Abustan I, Ahmad MA, Foul AA (2013) Cadmium removal from aqueous solution using microwaved olive stone activated carbon. J Environ Chem Eng 1(3):589-599

Altundogan SH, Bahar N, Mujde B, Tumen F (2007) The use of sulphuric acid-carbonization products of sugar beet pulp in Cr(VI) removal. J Hazard Mater 144(1-2):255-264

Alyüz B, Veli S (2009) Kinetics and equilibrium studies for the removal of nickel and zinc from aqueous solutions by ion exchange resins. J Hazard Mater 167:482-488

Aman T, Kazi AA, Sabri MU, Bano Q (2008) Potato peels as solid waste for the removal of heavy metal copper(II) from waste water/industrial effluent. Colloid Surf 63:116-121

Anandkumar J, Mandal B (2009) Removal of $\mathrm{Cr}(\mathrm{VI})$ from aqueous solution using Bael fruit (Aegle marmelos correa) shell as an adsorbent. J Hazard Mater 168:633-640

Apiratikul R, Pavasant P (2008) Sorption of $\mathrm{Cu}^{2+}, \mathrm{Cd}^{2+}$, and $\mathrm{Pb}^{2+}$ using modified zeolite from coal fly ash. Chem Eng J 144:245-258

Aydin H, Buluta Y, Yerlikayab C (2008) Removal of copper (II) from aqueous solution by adsorption onto low-cost adsorbents. J Environ Manage 87:37-45

Aziz HA, Adlan MN, Ariffin KS (2008) Heavy metals (Cd, Pb, Zn, $\mathrm{Ni}, \mathrm{Cu}$ and $\mathrm{Cr}(\mathrm{III}))$ removal from water in Malaysia: post treatment by high quality limestone. Bioresour Technol 99:1578-1583

Babarinde NAA, Babalola JO, Sanni RA (2006) Biosorption of lead ions from aqueous solution by maize leaf. Intl J Phys Sci 1(1):23-26

Babel S, Kurniawan TA (2004) Cr(VI) removal from synthetic wastewater using coconut shell charcoal and commercial activated carbon modified with oxidizing agents and/or chitosan. Chemosphere 54:951-967

Babu BV, Gupta S (2008) Adsorption of Cr(VI) using activated neem leaves: kinetic studies. Adsorption 14:85-92

Barakat MA (2011) New trends in removing heavy metals from industrial wastewater. Arab J Chem 4:361-377

Barka N, Abdennouri M, El Makhfouk M, Qourzal S (2013) Biosorption characteristics of cadmium and lead onto ecofriendly dried cactus (Opuntia ficus indica) cladodes. J Environ Chem Eng 1(3): 144-149

Barrera H, Ureńa-Núńez F, Bilyeu B, Barrera-Díaz C (2006) Removal of chromium and toxic ions present in mine drainage by ectodermis of opuntia. J Hazard Mater 136:846-853

Basaldella EI, Vazquez PG, Iucolano F, Caputo D (2007) Chromium removal from water using LTA zeolites: effect of $\mathrm{pH}$. J Colloid Interface Sci 313:574-578

Benaïssa H, Elouchdi MA (2007) Removal of copper ions from aqueous solution by dried sunflower leaves. Chem Eng Process 46:614-622
Bertocchi AF, Ghiani M, Peretti R, Zucca A (2006) Red mud and fly ash for mine site contaminated with $\mathrm{As}, \mathrm{Cd}, \mathrm{Cu}, \mathrm{Pb}$ and $\mathrm{Zn}$. J Hazard Mater 134:112-119

Betancur M, Bonelli PR, Velásquez JA, Cukierman AL (2009) Potentiality of lignin from the kraft pulping process for removal of trace nickel from wastewater: effect of demineralization. Bioresour Technol 100:1130-1137

Bhatti HN, Nasir AW, Hanif MA (2010) Efficacy of Daucas carota L. waste biomass for the removal of chromium from aqueous solutions. Desalination 253(1-3):78-87

Bishnoi NR, Bajaj M, Sharma N, Gupta A (2004) Adsorption of $\mathrm{Cr}(\mathrm{VI})$ on activated rice husk carbon and activated alumina. Bioresour Technol 91:305-307

Bose A, Kavitha B, Keharia H (2011) The suitability of jatropha seed press cake as a biosorbent for removal of hexavalent chromium from aqueous solutions. Bioremediat J 15(4):218-229

Bratskaya SY, Pestov AV, Yatluk YG, Avramenko VA (2009) Heavy metals removal by flocculation/precipitation using $\mathrm{N}$-(2-carboxyethyl)chitosans. Colloid Surf 339:140-144

Brown PA, Gill SA, Allen SJ (2000) Metal removal from wastewater using peat. Water Res 34(16):3907-3916

Buasri A, Chaiyut N, Tapang K, Jaroensin S, Panphrom S (2012) Equilibrium and kinetic studies of biosorption of $\mathrm{Zn}$ (II) ions from wastewater using modified corncob. APCBEE Procedia 3:60-64

Cagnon B, Py X, Guillot A, Stoeckli F, Chambat G (2009) Contributions of hemicellulose, cellulose and lignin to the mass and the porous properties of chars and steam activated carbons from various lignocellulosic precursors. Bioresour Technol 100:292-298

Chandra R, Takeuchi H, Hasegawa T (2012) Methane production from lignocellulosic agricultural crop wastes: a review in context to second generation of biofuel production. Renew Sustain Energy Rev 16:1462-1476

Chang Q, Wang G (2007) Study on the macromolecular coagulant PEX which traps heavy metals. Chem Eng Sci 62:4636-4643

Chang Q, Zhang M, Wang JX (2009) Removal of $\mathrm{Cu}^{2+}$ and turbidity from wastewater by mercaptoacetyl chitosan. J Hazard Mater 169:621-625

Chen H, Han Y, Xu J (2008) Simultaneous saccharification and fermentation of steam exploded wheat straw pretreated with alkaline peroxide. Process Biochem 43:1462-1466

Chockalingam E, Subramanian S (2006) Studies on removal of metal ions and sulphate reduction using rice husk and Desulfotomaculum nigrificans with reference to remediation of acid mine drainage. Chemosphere 62:699-708

Chojnacka K (2006) Biosorption of $\mathrm{Cr}(\mathrm{III})$ ions by wheat straw and grass: a systematic characterization of new biosorbents. Pol J Environ Stud 15:845-852

Chong HLH, Chia PS, Ahmad MN (2013) The adsorption of heavy metal by Bornean oil palm shell and its potential application as constructed wetland media. Bioresour Technol 130:181-186

Cifuentes L, García I, Arriagada P, Casas JM (2009) The use of electrodialysis for metal separation and water recovery from $\mathrm{CuSO}_{4}-\mathrm{H}_{2} \mathrm{SO}_{4}-\mathrm{Fe}$ solutions. Sep Purif Technol 68:105-108

Cséfalvay E, Pauer V, Mizsey P (2009) Recovery of copper from process waters by nanofiltration and reverse osmosis. Desalination 240:132-142

Dakiky M, Khamis M, Manassra A, Mereb M (2002) Selective adsorption of chromium (VI) in industrial wastewater using lowcost abundantly available adsorbents. Adv Environ Res 6:533-540

Dadhlich AS, Beebi SK, Kavitha GV (2004) Adsorption of Ni(II) using, rice husk. J Environ Sci Eng 46:179-185 
Daneshwar N, Salari D, Aber A (2002) Chromium adsorption and $\mathrm{Cr}(\mathrm{VI})$ reduction to trivalent chromium in aqueous solution by soya cake. J Hazard Mater B94:49-60

Dang VBH, Doan HD, Dang-Vu T, Lohi A (2009) Equilibrium and kinetics of biosorption of cadmium (II) and copper (II) ions by wheat straw. Bioresour Technol 100:211-219

Demiral H, Demiral I, Karabacakoglu B, Tumsek F (2011) Production of activated carbon from olive bagasse by physical activation. Chem Eng Design 89:206-213

Demirbas A (2004) Combustion characteristics of different biomass fuels. Prog Energy Combust Sci 30:219-230

Demirbas A (2008a) The sustainability of combustible renewables. Energy sources A 30(12):1114-1119

Demirbas E (2008b) Heavy metal adsorption onto agro-based waste materials: a review. J Hazard Mater 157:220-229

Demirbas A (2009) Biorefineries: current activities and future developments. Energy Convers Manage 50:2782-2801

Dhakal RP, Ghimire KN, Inoue K (2005) Adsorptive separation of heavy metals from an aquatic environment using orange waste. Hydrometallurgy 79:182-190

Dhir B, Kumar R (2010) Adsorption of heavy metals by salvinia biomass and agricultural residues. Int J Environ Res 4:427-432

Dialynas E, Diamadopoulos E (2009) Integration of a membrane bioreactor coupled with reverse osmosis for advanced treatment of municipal wastewater. Desalination 238:302-311

Doke KM, Khan EM (2012) Equilibrium, kinetic and diffusion mechanism of $\mathrm{Cr}(\mathrm{VI})$ adsorption onto activated carbon derived from wood apple shell. Arab J Chem. doi:10.1016/j.arabjc.2012. 07.031 (article in press)

Duan JC, Lu Q, Chen RW, Duan YQ, Wang LF, Gao L, Pan SY (2010) Synthesis of a novel flocculant on the basis of crosslinked Konjac glucomannan-graftpolyacrylamide-co-sodium xanthate and its application in removal of $\mathrm{Cu}^{2+}$ ion. Carbohydr Polym 80:436-441

El Samrani AG, Lartiges BS, Villiéras F (2008) Chemical coagulation of combined sewer overflow: heavy metal removal and treatment optimization. Water Res 42:951-960

Elouear Z, Bowid J, Boujelben N, Feki M, Montiel A (2008) The use of exhausted olive cake ash (EOCA) as a low cost adsorbent for the removal of toxic metal ions from aqueous solutions. Fuel 87:2582-2589

Erikson P (1988) Nanofiltration extends the range of membrane filtration. Environ Prog 7:58-61

Farajzadeh MF, Monji AB (2004) Adsorption characteristics of wheat bran, towards heavy metal cations. Sep Sci Technol 38:197-207

Farinella NV, Matos GD, Arruda MAZ (2007) Grape bagasse as a potential biosorbent of metals in effluent treatments. Bioresour Technol 98:1940-1946

Farinella NV, Matos GD, Lehman EL, Arruda MAZ (2008) Grape bagasse as an alternative natural adsorbent of cadmium and lead for effluent treatment. J Hazard Mater 154(1-3):1007-1012

Farooq U, Khan MA, Atharc M, Kozinskia JA (2011) Effect of modification of environmentally friendly bioadsorbents wheat (Triticum aestivum) on the biosorptive removal of cadmium(II) ions from aqueous solution. Chem Eng J 171:400-410

Faust SD, Aly OM (1987) Adsorption processes for water treatment. Butterworth Publishers, Stoneham

Feng N, Guo X, Liang S, Zhu Y, Liu J (2011) Biosorption of heavy metals from aqueous solutions by chemically modified orange peel. J Hazard Mater 185:49-54

Feng J, Hong QY, Green AES (2006) Analytical model of corn cob pyroprobe-FTIR data. Biomass Bioenerg 30:486-492

Fernandez Y, Maranon E, Costrillon L, Vazquez I (2005) Removal of $\mathrm{Cd}$ and $\mathrm{Zn}$ from inorganic industrial waste leachate by ion exchange. J Hazard Mater 126(1-3):169-175
Figoli A, Cassano A, Criscuoli A, Mozumder MSI, Uddin MT, Islam MA, Drioli E (2010) Influence of operating parameters on the arsenic removal by nanofiltration. Water Res 44:97-104

Fiol N, Villaescus I, Martinez M, Miralles N, Poch J, Serarols J (2006) Sorption of $\mathrm{Pb}(\mathrm{II}), \mathrm{Ni}(\mathrm{II}), \mathrm{Cu}(\mathrm{II})$, and $\mathrm{Cu}(\mathrm{II})$ from aqueous solution by olive stone waste. Sep Purif Technol $50: 132-140$

Fu F, Wang Q (2011) Removal of heavy metal ions from wastewaters: a review. J Environ Manag 92:407-418

Gamage A, Shahidi F (2007) Use of chitosan for the removal of metal ion contaminants and proteins from water. Food Chem 104(3):989-996

Gill R, Mahmood A, Nazir R (2013) Biosorption potential and kinetic studies of vegetable waste mixture for the removal of nickel(II). J Hazard Mater Cycle Waste Manag 15:115-121

Grover PD, Iyer PVR, Rao TR (2002) Biomass-thermochemical characterization, 3rd edn. IIT Delhi MNES

Gu XY, Evans LJ (2008) Surface complexation modelling of Cd(II), $\mathrm{Cu}(\mathrm{II}), \mathrm{Ni}(\mathrm{II}), \mathrm{Pb}(\mathrm{II})$ and $\mathrm{Zn}(\mathrm{II})$ adsorption onto kaolinite. Geochim Cosmochim Acta 72:267-276

Guechi EK, Hamdaowio O (2015) Evaluation of potato peel as a novel adsorbent for the removal of $\mathrm{Cu}$ (II) from aqueous solutions: equilibrium, kinetics and thermodynamic studies. Desalinat Water Treat 57(23):10677-10688

Gundogdu A, Ozdes D, Duran C, Bulut VN, Soylak M (2009) Biosorption of $\mathrm{Pb}(\mathrm{II})$ ions from aqueous solution by pine bark (Pinus brutia Ten). Chem Eng J 153:62-69

Guo MX, Qiu GN, Song WP (2010) Poultry litter-based activated carbon for removing heavy metal ions in water. Waste Manage 30:308-315

Gupta VK, Ali I (2000) Utilization of bagasse fly ash (a sugar industry waste) for the removal of copper and zinc from wastewater. Sep Purif Technol 18:131-140

Gupta S, Babu BV (2009) Utilization of waste product (tamarind seeds) for the removal of $\mathrm{Cr}(\mathrm{VI})$ from aqueous solutions: equilibrium, kinetics, and regeneration studies. J Environ Manag 90:3013-3022

Gupta VK, Gupta M, Sharma M (2001) Process development for the removal of lead and chromium from aqueous solution using red mud-an aluminium industry waste. Water Res 35(5):1125-1134

Gupta BS, Curran M, Hosan S, Ghos TK (2009) Adsorption characteristics of $\mathrm{Cu}$ and $\mathrm{Ni}$ on Irish peat moss. J Env Manag 90:954-960

Gupta VK, Rastogi A, Nayak A (2010) Adsorption studies on the removal of hexavalent chromium from aqueous solution using a low cost material. J Colloid Interface Sci 342(1):135-141

Gupta VK, Srivastava SK, Mohan D, Sharma S (1997) Design parameters for fixed bed reactors of activated carbon developed from fertilizers waste for the removal of some heavy metal ions. Waste Manag 17(8):517-522

Hamissa AMB, Lodi A, Seffen M, Finocchio E, Botter R, Converti A (2010) Sorption of $\mathrm{Cd}(\mathrm{II})$ and $\mathrm{Pb}$ (II) from aqueous solutions onto Agave americana fibers. Chem Eng J 159:67-74

Hanra MS, Ramchandran V (1996) Trace level separation of zinc sulphate and lead nitrate from toxic effluent streams by reverse osmosis modular systems. Sep Sci Technol 31(1):49-61

Heidmann I, Calmano W (2008) Removal of Zn(II), Cu(II), Ni(II), $\mathrm{Ag}(\mathrm{I})$ and $\mathrm{Cr}(\mathrm{VI})$ present in aqueous solutions by aluminium electrocoagulation. J Hazard Mater 152:934-941

Henryk K, Jaraslaw C, Witold Z (2016) Peat and coconut fiber as biofilters for chromium adsorption from contaminated wastewaters. Environ Sci Pollut Res 23:527-534

Ho YS (2003) Removal of copper ions from aqueous solution by tree fern. Water Res 37:2323-2330 
Ho YS, Mckay G (2004) Sorption of copper(II) from aqueous solution by peat. Water Air Soil Pollut 158:77-97

Ho Y, Ofomaja AE (2006) Biosorption thermodynamics of cadmium on coconut copra meal as biosorbent. Biochem Eng J 30:117-123

Horsfall M, Spiff AI, Abia AA (2004) studies on the influence of mercaptoacetic acid(MAA) waste biomass on the adsorption of $\mathrm{Cu}^{2+}$ and $\mathrm{Cd}^{2+}$ from aqueous solution. Bull Korean Chem Soc 29:969-976

Hossain MA, Ngo NN, Guo WS, Setiadi GT (2012) Adsorption and desorption of copper(II) ions onto garden grass. Bioresour Technol 121:386-395

Hossain MA, Ngo HH, Guo WS, Nguyan TV, Vigneswaran S (2014) Performance of cabbage and cauliflower wastes for heavy metal removal. Desali Water Treat 52(1-2):844-860

Huang K, Zhu H (2013) Removal of $\mathrm{Pb}^{2+}$ from aqueous solution by adsorption on chemically modified muskmelon peel. Environ Sci Pollut Res 20:4424-4434

Huber GW, Iborra S, Corma A (2006) Synthesis of transportation fuels from biomass: chemistry, catalysts, and engineering. Chem Rev 106:4044-4098

Iqbal M, Saeed A, Zafar SI (2009a) FTIR spectrophotometry, kinetics and adsorption isotherms modeling, ion exchange, and EDX analysis for understanding the mechanism of $\mathrm{Cd}^{2+}$ and $\mathrm{Pb}^{2+}$ removal by mango peel waste. J Hazard Mater 164:161-171

Iqbal M, Saeed A, Kalim I (2009b) Characterization of adsorptive capacity and investigation of mechanism of $\mathrm{Cu}^{2+}, \mathrm{Ni}^{2+}$ and $\mathrm{Zn}^{2+}$ adsorption on mango peel waste from constituted metal solution and genuine electroplating effluent. Sep Sci Technol 44:3770-3791

Ismaiel AA, Aroua MK, Yusoff R (2013) Palm shell activated carbon impregnated with task-specific ionic-liquids as a novel adsorbent for the removal of mercury from contaminated water. Chem Eng J 225:306-314

Jain M, Garg VK, Kadirvelu K (2013) Cadmium(II) sorption and desorption in a fixed bed column using sunflower waste carbon calcium-alginate beads. Bioresour Technol 129:242-248

Jalali M, Aboulghazi F (2013) Sunflower stalk, an agricultural waste, as an adsorbent for the removal of lead and cadmium from aqueous solutions. J Mater Cycles Waste Manag 15:548-555

Janaki V, Kamala-Kannan S, Shanthi K (2015) Significance of Indian peat moss for the removal of $\mathrm{Ni}(\mathrm{II})$ ions from aqueous solution. Environ Earth Sci 74(6):5351-5357

Jayaram K, Prasad MNV (2009) Removal of Pb(II) from aqueous solution by seed powder of Prosopis juliflora DC. J Hazard Mater 169:991-997

Kaczala F, Marques M, Hogland W (2009) Lead and vanadium removal from a real industrial wastewater by gravitational settling/sedimentation and sorption onto Pinus sylvestris sawdust. Bioresour Technol 100:235-243

Kang KC, Kim SS, Choi JW, Kwon SH (2008) Sorption of $\mathrm{Cu}^{2+}$ and $\mathrm{Cd}^{2+}$ onto acid and base-pretreated granular activated carbon and activated carbon fibre samples. J Ind Eng Chem 14:131-135

Kapur M, Mondal MK (2013) Mass transfer and related phenomena for $\mathrm{Cr}(\mathrm{VI})$ adsorption from aqueous solutions onto Mangifera indica sawdust. Chem Eng J 218:138-146

Karthikeyan KG, Elliott HA, Cannon FS (1996) Enhanced metal removal from wastewater by coagulant addition. In: Proceedings of 50th Purdue Industrial Waste Conference 50:259-267

Kataki R, Konwer D (2001) Fuelwood characteristics of some indigenous woody species of north-east India. Biomass Bioenergy 20:17-23

Kelly-Vargas K, Cerro-lopez M, Reyna-Tellez S, Bandala ER, Sanchez-Sales JL (2012) Biosorption of heavy metals in polluted water using different waste fruit cortex. Phys Chem Earth Parts A B C 37-39:26-29
Keng P-S, Lee S-L, Ha S-T, Hung Y-T, Ong S-T (2013) Cheap material to clean heavy metal polluted waters, In: Lichtfouse E et al. (eds) Green materials for energy, Products and Depollution, Environmental Chemistry for a Sustainable World 3, Springer Science+Business Media Dardrecht, pp 339-351

Khan NA, Ali SI, Ayub S (2001) Effect of pH on the removal of chromium (Cr) (VI) by sugar cane baggase. Sep Sci Technol 6:13-19

Khan MA, Ngabura M, Choong TSY, Masood H, Chuah LA (2012) Biosorption and adsorption of nickel on oil cake: batch and column studies. Bioresour Technol 13(1):35-42

Kim DH, Shin MC, Choi HD, Cl Seo, Baek K (2008) Removal mechanism of copper using steel making slag: adsorption and precipitation. Desalination 223(1-3):283-289

Kohler SJ, Cubillas P, Rodriguez-Blanco JD, Bauer C, Prieto M (2007) Removal of cadmium from wastewaters by aragonite shells and the influence of other divalent cations. Environ Sci Technol 41:112-118

Kongsuwan A, Patnukao P, Pavasant P (2009) Binary component sorption of $\mathrm{Cu}$ (II) and $\mathrm{Pb}$ (II) with activated carbon from Eucalyptus camaldulensis Dehn bark. J Ind Eng Chem 15:465-470

Kononova ON, Kholmogorov AG, Kachin SV, Mytykh OV, Konovova YS, Kalyakina OP, Pashkov GL (2000) Ion exchange recovery of nickel from manganese nitrate solutions. Hydrometallurgy 54:107-115

Konstantinou M, Kolokassidou K, Pashalidis I (2007) Sorption of $\mathrm{Cu}$ (II) and $\mathrm{Eu}(\mathrm{II})$ ions from aqueous solution by oliove cake. Adsorption 13:33-40

Koroki M, Saito S, Hashimoto H, Yamada T, Aoyoma M (2010) Removal of $\mathrm{Cr}(\mathrm{VI})$ from aqueous solutions by the clum of bamboo grass treated with concentrated sulfuric acid. Environ Chem Lett 8:197-207

Kristensen O (1996) Combined heat and power production based on gasification of straw and woodchips. In: Chartier P, Ferrero GL, Henius UM, Hultberg S, Sachau J, Wiinblad M (eds) Proceedings of the 9th European bioenergy conference, 1996, Copenhagen, vol 1. Pergamon, Elsevier Science Ltd., Oxford, pp 272-277

Kryvoruchko A, Yurlova AL, Karnilovich B (2002) Purification of water containing heavy metals by chelating-enhanced ultrafilteration. Desalination 144:243-248

$\mathrm{Ku} \mathrm{Y}$, Jung IL (2001) Photocatalytic reduction of $\mathrm{Cr}(\mathrm{VI})$ in aqueous solutions by UV irradiation with the presence of titanium dioxide. Water Res 35:135-142

Kumar PS, Ramalingam S, Kirupha SD, Murugesan A, Vidyadevii T, Sivanesan S (2011) Adsorption behaviour of nickel(II) onto cashew nut shell: equilibrium, thermodynamic, mechanism and process design. Chem Eng J 167:122-131

Kumar PS, Ramalingam S, Sathyaselvabala V, Kirupha SD, Murugesa A, Sivanesan S (2012a) Removal of cadmium(II) from aqueous solution by agricultural waste cashew nut shell. Korean J Chem Eng 29(6):756-768

Kumar PS, Gayathri R, Senthamarai C, Priyadharshini M, Fernando PSA, Srinath R, Kumar VV (2012b) Kinetics, mechanism, isotherm and thermodynamic analysis of adsorption of cadmium ions by surface-modified Strychnos potatorum seeds. Korean J Chem Eng 29(12):1752-1760

Landaburu-Aguirre J, García V, Pongrácz E, Keiski RL (2009) The removal of zinc from synthetic wastewaters by micellarenhanced ultrafiltration: statistical design of experiments. Desalination 240:262-269

Landaburu-Aguirre J, Pongracz E, Sarpola A (2012) Simultaneous removal of heavy metals from phosphorous rich real wastewater by micellar-enhanced ultrafiltration. Sep Purif Technol $88: 130-137$ 
Lasheen MR, Ammar NS, Ibrahim HS (2012) Adsorption/desorption of $\mathrm{Cd}(\mathrm{II}), \mathrm{Cu}(\mathrm{II})$ and $\mathrm{Pb}(\mathrm{II})$ using chemically modified orange peel: equilibrium and kinetic studies. Solid State Sci 14(2):202-210

Lee SJ, Park JH, Ahn YT, Chung JW (2015) Comparison of heavy metal adsorption by peat moss and peat moss-derived biochar produced under different carbonization conditions. Water Air Soil Pollut 226:9

Leyva-Ramos R, Bernal-Jacome LA, Acosta-Rodriguez I (2005) Adsorption of cadmium (II) from aqueous solution on natural and oxidized corncob. Sep Purif Technol 45:41-49

Li MS, Fan YM, Xu F, Sun RC, Zhang XL (2010) Cold sodium hydroxide/urea based pretreatment of bamboo for bioethanol production: characterization of the cellulose rich fraction. Ind Crops Prod 32:551-559

Liu ZR, Zhou LM, Wei P, Zeng K, Wen CX, Lan HH (2008) Competitive adsorption of heavy metal ions on peat. J China Univ Min Technol 18:255-260

Liu ZR, Chen XS, Zhou LM, Peng WEI (2009) Development of a first-order kinetic based model for the adsorption of nickel onto peel. Mining Sci Technol (China) 19(2):230-243

López FA, Centeno TA, García-Díaz I, Alguacil FJ (2013) Texture and fuel characteristics of the char produced by the pyrolysis of waste wood, and the properties of activated carbons prepared from them. J Anal Appl Pyrolysis 104:551-558

Low KS, Lee CK, Leo AC (1995) Removal of metals from electroplating wastes using banana pith. Bioresour Technol $51: 227-231$

Lu AH, Zhong SJ, Chen J, Shi JX, Tang JL, Lu XY (2006) Removal of $\mathrm{Cr}(\mathrm{VI})$ and $\mathrm{Cr}(\mathrm{III})$ from aqueous solutions and industrial wastewaters by natural clinopyrrhotite. Environ Sci Technol 40:3064-3069

Lundh M, Jönsson L, Dahlquist J (2000) Experimental studies of the fluid dynamics in the separation zone in dissolved air flotation. Water Res 34:21-30

Mahvi AH, Maleki A, Eslami A (2004) Potential of rice husk and rice husk ash for phenol removal in aqueous systems. Am J Appl Sci 1(4):321-326

Malathi S, Krishnaveni N, Sudha R (2015) Adsorptive removal of lead(II) from an aqueous solution by chemically modified cottonseed cake. Res Chem Intermed. doi:10.1007/s11164-015$2149-4$

Malkoc E, Nuhoglu Y (2005) Investigation of Ni II removal from aqueous solutions using tea factory waste. J Hazard Mater B127:120-128

Maranon E, Sastre H (1991) Heavy metal removal in packed beds using apple wastes. Bioresour Technol 38:39-43

Maranon E, Swarez F, Alonso F, Fernandez Y, Sastre H (1999) Preliminary study of iron removal from hydrochloric pickling liquor by iron exchange. Ind Eng Chem Res 38:2782-2786

Márquez-Reyes JM, López-Chuken UJ, Valdez-González A, LunaOlvera HA (2013) Removal of chromium and lead by a sulfatereducing consortium using peat moss as carbon source. Bioresour Technol 144:128-134

Marshall WE, Champagne ET, Evans WJ (1993) Use of rice milling byproducts (hulls and bran) to remove metal ions from aqueous solution. J Environ Sci Health A 28:1977-1992

Martins AE, Pereira MS, Jorgetto AO, Martines MAU, Silva RIV, Saekia MJ, Castro GR (2013) The reactive surface of Castor leaf [Ricinus communis L.] powder as a green adsorbent for the removal of heavy metals from natural river water. Appl Surf Sci 276:24-30

McKendry P (2002) Energy production from biomass (part 1): overview of biomass. Bioresour Technol 83:37-46

Memon JR, Memon SQ, Bhanger MI, Memon GZ, El-Turki A, Allen GC (2008) Characterization of banana peel by scanning electron microscopy and FT-IR spectroscopy and its use for cadmium removal. Colloids Surf B Biointerfaces 66:260-265

Memon JR, Memon SQ, Bhanger MI, El-Turki A, Keith R, Hallam Allen GC (2009) Banana peel: a green and economical sorbent for the selective removal of $\mathrm{Cr}(\mathrm{VI})$ from industrial wastewater. Colloids Surf B Biointerfaces 70:232-237

Mendez A, Barriya S, Fidalgo JM, Gasco G (2009) Adsorbent material from paper industry waste materials and their use in $\mathrm{Cu}$ (II) removal from water. J Hazard Mater 165(1-3):736-743

Meneghel AP, Goncalves AC Jr, Strey L, Rubio T, Schwantes D, Casarin J (2013) Biosorption and removal of chromium from water by using moringa seed cake (Moringa oleifera Lam.). Quim Nova 36(8):104-110

Mirbagherp SA, Hosseini SN (2004) Pilot plant investigation on petrochemical wastewater treatment for the removal of copper and chromium with the objective of reuse. Desalination 171:85-93

Mishra SP, Dubey SS, Tiwari D (2004) Rapid and efficient removal of $\mathrm{Hg}$ (II) by hydrous manganese and tin oxides. J Colloid Interface Sci 279:61-67

Mohammad AW, Othman R, Hilal N (2004) Potential use of nanofiltration membranes in treatment of industrial wastewater from Ni-P electroless plating. Desalination 168:241-252

Mohammad AAG, Juiki L, Yousel S, Nasir AL, Gavin W, Mohammad NMA (2010) Adsorption mechanism of remaining heavy metals and dyes from aqueous solution using date pits solid adsorbent. J Hazard Mater 185:401-407

Mohammadi T, Moheb A, Sadrzadeh M, Razmi A (2005) Modelling of metal ion removal from wastewater by electrodialysis. Sep Purif Technol 41:73-82

Mohammadi SZ, Karimi MA, Afzali D, Mansouri F (2010) Removal of $\mathrm{Pb}$ (II) from aqueous solutions using activated carbon from sea-buckthorm stones by chemical activation. Desalination 262(1-3):86-93

Mohammod M, Sen TK, Maitra S, Dutta BK (2011) Removal of $\mathrm{Zn}^{2+}$ from aqueous solution using castor seed hull. Water Air Soil Pollut 215:609-620

Mohan D, Singh KP (2002) Single- and multi-component adsorption of cadmium and zinc using activated carbon derived from bagasse-an agricultural waste. Water Res 36:2304-2318

Mohan S, Sreelakshmi G (2008) Fixed bed column study for heavy metal removal using phosphate treated rice husk. J Hazard Mater 153:75-82

Mohsen-Nia M, Montazeri P, Modaress H (2007) Removal of $\mathrm{Cu}^{2+}$ and $\mathrm{Ni}^{2+}$ from wastewater with a chelating agent and reverse osmosis processes. Desalination 217:276-281

Molinari R, Poerio T, Argurio P (2008) Selevtive separation of copper (II) and nickel (II) from aqueous media using the complexationutrafiltration process. Chemosphere 70(3):341-348

Mondal MK (2010) Removal of Pb(II) from aqueous solution by adsorption/desorption modified orange peel: Equilibrium and kinetic studies. Solid State Sci 14:202-210

Mondal MK (2012) Removal of Pb(II) from aqueous solution by adsorption using activated tea waste. Korean $\mathrm{J}$ Chem Eng 27(1):144-151

Mondal DK, Nandi BK, Purkait MK (2013) Removal of mercury (II) from aqueous solution using bamboo leaf powder: equilibrium, thermodynamic and kinetic studies. J Environ Chem Eng $1: 891-898$

Monteagudo JM, Ortiz MJ (2000) Removal of inorganic mercury from mine wastewater by ion exchange. J Chem Tech Biotechnol 75:767-772

Munagapati VS, Yarramuthi V, Nadavala SK, Alla SR, Abburi K (2010) Biosorption of $\mathrm{Cu}(\mathrm{II}), \mathrm{Cd}(\mathrm{II})$ and $\mathrm{Pb}(\mathrm{II})$ by Acacia leucocephala bark powder: kinetics, equilibrium and thermodynamics. Chem Eng J 157:357-365 
Murthy ZVP, Chaudhari LB (2008) Application of nanofiltration for the rejection of nickel ions from aqueous solutions and estimation of membrane transport parameters. J Hazard Mater 160:70-77

Muthukrishnan M, Guha BK (2008) Effect of $\mathrm{pH}$ on rejection of hexavalent chromium by nanofiltration. Desalination 219:171-178

Nadaroglu H, Kalkan E, Demir N (2010) Removal of copper from aqueous solution using red mud. Desalination 251:90-95

Nagah WSW, Hanafiah MAKM (2008) Removal of heavy metal ions from wastewater by chemically modified plant wastes as adsorbents: a review. Bioresour Technol 99:3935-3948

Nagashanmugam KB, Srinivasan K (2010) Evaluation of carbon derived fror Gingelly oil cake for the removal of lead(II) from aqueous solutions. J Environ Sci Eng 52(4):349-360

Naik S, Goud VV, Rout PK, Jacobson K, Dalai AK (2010) Characterization of Canadian biomass for alternative renewable biofuel. Renew Energy 35:1624-1631

Naiya TK, Bhattacharya AK, Mandal S, Das SK (2009) The sorption of lead (II) ions on rice husk ash. J Hazard Mater 163:1254-1264

Nakbanpote W, Thiravetyan P, Kalambaheti C (2000) Preconcentration of gold by rice husk ash. Miner Eng 13:391-400

Namasivayam C, Periasamy K (1993) Bicarbonate-treated peanut hull carbon for mercury(II) removal from aqueous solutions. Water Res 27:1663-1668

Nanseu-Njiki CP, Tchamango SR, Ngom PC, Darchen A, Ngameni E (2009) Mercury(II) removal from water by electrocoagulation using aluminium and iron electrodes. J Hazard Mater 168:1430-1436

Nataraj SK, Hosamani KM, Aminabhavi TM (2007) Potential application of an electrodialysis pilot plant containing ionexchange membranes in chromium removal. Desalination 217:181-190

Nguyen CM, Bang S, Cho J, Kim KW (2009) Performance and mechanism of arsenic removal from water by a nanofiltration membrane. Desalination 245:82-94

Okoye AI, Ejikeme PM, Onukwuli OD (2010) Lead removal from wastewater using fluted pumpkin seed hull activated carbon: adsorption modelling and kinetics. Int $\mathrm{J}$ Environ Sci Tech 7(4):793-800

Olguin MT, Lopez-Gonzalez H, Serrano-Gomez J (2013) Hexavalent chromium removal from aqueous solutions by Fe-modified peanut husk. Water Air Soil Pollut 224:1654

Oliveira FD, Paula J, Freitas OM, Figueiredo SA (2009) Copper and lead removal by peanut hulls: equilibrium and kinetic studies. Desalination 248:931-940

Onal Y, Akmil-Bas C, Sarıcı-Ozdemir C, Erdogan S (2007) Textural development of sugar beet bagasse activated with $\mathrm{ZnCl}_{2}$. J Hazard Mater 142:138-143

Ouensanga A, Largitte L, Arsene MA (2003) The dependence of char yield on the amounts of components in precursors for pyrolysed tropical fruit stones and seeds. Micropor Mesopor Mater 59:85-91

Ozer A, Ozer D (2004) The adsorption of copper(II) ions on to dehydrated wheat bran (DWB): determination of the equilibrium and thermodynamic parameters. Proc Biochem 39:2183-2191

Pagano M, Petruzzelli D, Tiravanti D, Passino R (2000) Pb/Fe separation and recovery from automobile battery wastewater by selective ion exchange. Solvent Extr Ion Exch 18:387-399

Pandey R, Prasad RL, Ansari NG, Murthy RC (2015) Utilization of $\mathrm{NaOH}$ modified Desmostachya bipinnata (kush grass) leaves and Bambusa aradinacea (bamboo) leaves for Cd(II) removal from aqueous solution. J Environ Chem Eng 3(1):593-602

Parab H, Joshi S, Shenoy N, Lali A, Sharma US, Sudersanan M (2006) Determination of kinetic and equilibrium parameters of the batch adsorption of $\mathrm{Co}(\mathrm{II}), \mathrm{Cr}(\mathrm{III})$ and $\mathrm{Ni}(\mathrm{II})$ onto coir pith. Process Biochem 41:609-615

Park HG, Kim TW, Chae MY, Yoo IK (2007) Activated carboncontaining alginate adsorbent for the simultaneous removal of heavy metals and toxic organics. Process Biochem 42:1371-1377

Pehlivan E, Altun T (2008) Bioadsorption of chromium(VI) ion from aqueous solutions using walnut, hazelnut and almond shell. J Hazard Mater 155:378-384

Pehlivan E, Altun T, Cetin S, Bhanger MI (2009a) Lead sorption by waste biomass of hazelnut and almond shell. J Hazard Mater 167:1203-2128

Pehlivan E, Altun T, Parlayici S (2009b) Utilization of barley straws as biosorbents for $\mathrm{Cu}^{2+}$ and $\mathrm{Pb}^{2+}$ ions. J Hazard Mater 164:982-986

Pehlivan E, Altun T, Cetin S, Bhangerb MI (2009c) Lead sorption by waste biomass of hazelnut and almond shell. J Hazard Mater 167:1203-1208

Pettersson A, Amand L-E, Steenari B-M (2008) Leaching of ashes from co-combustion of sewage sludge and wood-part I: recovery of phosphorus. Biomass Bioenergy 32:224-235

Polat H, Erdogan D (2007) Heavy metal removal from wastewater by ion flotation. J Hazard Mater 148:267-273

Prasad S, Singh A, Joshi HC (2007) Ethanol as an alternative fuel from agricultural, industrial and urban residues. Resour Conserv Recycl 50:1-39

Rafatullah M, Sulaiman O, Hashim R, Ahmad A (2012) Removal of cadmium (II) from aqueous solutions by adsorption using meranti wood. Wood Sci Technol 46:221-241

Rao M, Parwate AV, Bhole AG (2002) Removal of Cr(VI) and Ni(II) from aqueous solution using bagasse and fly ash. Waste Manage $22: 821-830$

Rashed MN (2006) Fruit stones from industrial waste for the removal of lead ions from polluted water. Environ Monit Assess 119:31-41

Raveendran K, Ganesh A, Khilar K (1995) Influence of mineral matter on biomass pyrolysis characteristics. Fuel 74:1812-1822

Reddy N, Yang Y (2005) Biofibers from agricultural byproducts for industrial applications. Trends Biotechnol 23(1):22-27

Reddy DHK, Seshaiaha K, Reddy AVR, Raoc MM, Wang MC (2010) Biosorption of $\mathrm{Pb}^{2+}$ from aqueous solutions by Moringa oleifera bark: equilibrium and kinetic studies. J Hazard Mater 174:831-838

Reddy DHK, Ramana DKV, Seshaiah Reddy AVR (2011) Biosorption of $\mathrm{Ni}(\mathrm{II})$ from aqueous phase by Moringa oleifera bark, a low cost biosorbent. Desalination 268:150-157

Reyes I, Villarroel M, Diez MC, Navia R (2009) Using lignimerin (a recovered organic material from Kraft cellulose mill wastewater) as sorbent for $\mathrm{Cu}$ and $\mathrm{Zn}$ retention from aqueous solutions. Bioresour Technol 100:4676-4682

Sabry R, Hafez A, Khedr M, El-Hussanin A (2007) Removal of lead by an emulsion liquid membrane: part I. Desalination 212:165-175

Sadrzadeh M, Mohammadi T, Ivakpour J, Kasiri N (2008) Seperation of lead ions from wastewater using electrodialysis: comparing mathematical and neural network modelling. Chem Eng J 144:431-441

Sadrzadeha M, Mohammadi T, Ivakpour J, Kasiri N (2009) Neural network modelling of $\mathrm{Pb}^{2+}$ removal from wastewater using electrodialysis. Chem Eng Process 48:1371-1381

Saeed A, Iqbal M, Akhtar W (2005) Removal and recovery of lead(II) from single and multimetal $(\mathrm{Cd}, \mathrm{Cu}, \mathrm{Ni}, \mathrm{Zn})$ solutions by crop milling waste (black gram husk). J Hazard Mater 11:65-73

Saha R, Mukherjee K, Saha I, Ghosh A, Ghosh SK, Saha B (2013) Removal of hexavalent chromium from water by adsorption on 
mosambi (Citrus limetta) peel. Res Chem Intermed 39:2245-2257

Sahu MK, Mandal S, Dash SS, Badhai P, Patel RK (2013) Removal of $\mathrm{Pb}$ (II) from aqueous solution by acid activated red mud. J Environ Chem Eng 1(4):1315-1324

Sampera E, Rodrígueza M, De la Rubia MA, Prats D (2009) Removal of metal ions at low concentration by micellar-enhanced ultrafiltration (MEUF) using sodium dodecyl sulfate (SDS) and linear alkylbenzene sulfonate (LAS). Sep Purif Technol 65:337-342

Sander B (1997) Properties of Danish biofuels and the requirements for power production. Biomass Bioenergy 12:177-183

Sarin V, Pant KK (2006) Removal of chromium from industrial waste by using eucalyptus bark. Bioresour Technol 97(1):15-20

Sassi M, Bestani B, Said AH, Benderdouche N, Guibal E (2010) Removal of heavy metal ions from aqueous solution by a local dairy sludges as a biosorbent. Desalination 262:243-250

Scatchard G (1949) The attractions of proteins for small molecules and ions. Ann Acad Sci N Y 51:600-672

Schiewer S, Patil SB (2008) Modeling the effect of $\mathrm{pH}$ on biosorption of heavy metals by citrus peels. J Hazard Mater 157:8-17

Scurlock JMO, Dayton DC, Hames BB (2000) An overlooked biomass resource? Biomass Bioenergy 19:229-244

Semerjian L, Ayoub GM (2003) High-pH-magnesium coagulationflocculation in wastewater treatment. Adv Environ Res 7:389-403

Şensöz S, Demiral İ, Gercel HF (2006) Olive bagasse (Olea europea L.) pyrolysis. Bioresour Technol 97(3):429-436

Shafique U, Ijaz A, Salman M, Zaman W, Jamil N, Rehman R, Javaid A (2012) Removal of arsenic from water using pine leaves. J Taiwan Inst Chem Eng 43:256-263

Shahalam AM, Al-Harthy A, Al-Zawhry A (2002) Feed water pretreatment in RO systems in the Middle East. Desalination $150: 235-245$

Shammas NK (2004) Coagulation and flocculation. In: Wang LK, Hung YT, Shammas NK (eds) Physicochemical treatment processes, vol 3. Humana Press, New Jersey, pp 103-140

Shen DK, Gu S, Luo KH, Bridgwater AV, Fang MX (2009) Kinetic study on thermal decomposition of woods in oxidative environment. Fuel 88:1024-1030

Sheng GD, Wang SW, Hua J, Lu Y, Li JX, Dong YH, Wang XK (2009) Adsorption of $\mathrm{Pb}(\mathrm{II})$ on diatomite as affected via aqueous solution chemistry and temperature. Colloid Surf 339:159-166

Shukla SR, Pai RS (2005) Adsorption of $\mathrm{Cu}(\mathrm{II}), \mathrm{Ni}(\mathrm{II})$ and $\mathrm{Zn}$ (II) on modified jute fibres. Bioresour Technol 96:1430-1438

Shukla SR, Pai RS, Shendarkar AD (2006) Adsorption of Ni(II), $\mathrm{Zn}(\mathrm{II})$ and $\mathrm{Fe}(\mathrm{II})$ on modified coir fibres. Sep Purif Technol 47:141-147

Sobhanardakani S, Parvizimosaed H, Olyaie E (2013) Heavy metals removal from wastewaters using organic solid waste-rice husk. Environ Sci Pollut Res 20:5265-5271

Soliman EM, Ahmad SA, Fadl AA (2011) Reactivity of sugarcane bagasse as a natural solid phase extractor for selective removal of $\mathrm{Fe}(\mathrm{III})$ and heavy metal ions from natural water samples. Arab J Chem 4:63-70

Song S, Lopez-Valdivieso A, Hernandez-Campos DJ, Peng C, Monroy-Fernandez MG, Razo-Soto I (2006) Arsenic removal from high-arsenic water by enhanced coagulation with ferric ions and coarse calcite. Wat Res 40:364-372

Stniannopkao S, Sreesai S (2009) Utilization of pulp and paper industrial waste to remove heavy metal from metal finishing wastewater. J Environ Manag 90(11):3283-3289

Sud D, Mahajan G, Kaur MP (2008) Agricultural waste materials as potential adsorbent for sequestering heavy metal ions from aqueous solutions- a review. Bioresour Technol 99:6017-6027
Sun G, Shi W (1998) Sunflower stalks as adsorbents for the removal of metal ions from wastewater. Ind Eng Chem Res 37:1324-1328

Sun G, Xu X (1997) Sunflower stalks as adsorbents for color removal from textile wastewater. Ind Eng Chem Res 36:808-812

Szpyrkowicz L, Juzzolino C, Kaul SN (2001) A comparative study on oxidation of disperse dyes by electrochemical process, ozone, hypochlorite and fenton reagent. Water Res 35(9):2129-2136

Tamaki Y, Mazza G (2010) Measurement of structural carbohydrates, lignins, and micro-components of straw and shives: effects of extractives, particle size and crop species. Ind Crop Prod 31:534-541

Tan WT, Ooi ST, Lee CK (1993) Removal of chromium (VI) from solution by coconut husk and palm pressed fibres. Environ Technol 14:277-282

Taner F, Ardic I, Halisdemir B, Pehlivan E (2004) Biomass use and potential in Turkey. In: Biomass and agricultural: sustainability, markets and policies. OED publication

Tassel F, Rubio J, Misra M, Jena BC (1997) Removal of mercury from gold cyanide solution by dissolved air flotation. Miner Eng 10:803-811

Tazrouti N, Amrani M (2009) Chromium(VI) adsorption onto activated kraft lignin produced from alfa grass (Stipa tinacissima). Bio Resour 4(2):740-755

Tessele F, Misra M, Rubio J (1998) Removal of $\mathrm{Hg}$, As and Se ions from gold cyanide leach solutions by dissolved air flotation. Miner Eng 11:535-543

Tillman DA, Harding NS (2004) Fuels of opportunity: characteristics and uses in combustion systems. Elsevier B.V, Amsterdam, p 312

Tofan L, Teodosiu C, Paduraru C, Wenkert R (2013) Cobalt (II) removal from aqueous solutions by natural hemp fibers: batch and fixed-bed column studies. Appl Surf Sci. doi:10.1016/j. apsusc.2013.06.151

Trevino-Corderoa H, Juárez-Aguilara LG, Mendoza-Castilloa DI, Hernández-Montoyaa V, Bonilla-Petriciolet A, Montes-Moranb MA (2013) Synthesis and adsorption properties of activated carbons from biomass of Prunus domestica and Jacaranda mimosifolia for the removal of heavy metals and dyes from water. Ind Crops Prod 42:315-323

Vaughan T, Seo CW, Marshall WE (2001) Removal of selected metal ions from aqueous solution using modified corncobs. Bioresour Technol 78:133-139

Vlyssides AG, Israilides CJ (1997) Detoxification of tannery waste liquors with an electrolysis system. Env Pollut 97:147-152

Wartelle LH, Marshall WE (2006) Quaternized agricultural byproducts as anion exchange resins. $J$ Environ Manage $78: 157-162$

WASDE Report (2013) World wheat supply and use 524:18-19

Waters A (1990) Dissolved air flotation used as primary separation for heavy metal removal. Filtrat Sep 27(2):70-73

Williams PT, Reed AR (2006) Development of activated carbon pore structure via physical and chemical activation of biomass fibre waste. Biomass Bioenergy 30:144-152

Wong KK, Lee CC, Low KS, Haron MJ (2003) Removal of $\mathrm{Cu}$ and $\mathrm{Pb}$ by tartaric acid modified rice husk from aqueous solutions. Chemosphere 50:23-28

Yanik J, Ebale S, Kruse A, Saglam M, Yuksel M (2007) Biomass gasification in supercritical water: part 1, effect of the nature of biomass. Fuel 86:2410-2415

Yu HW, Samani Z, Hanson A, Smith G (2002) Energy recovery from grass using two-phase anaerobic digestion. Waste Manag 22:1-5

Yu JX, Wang LY, Chi RA, Zhang YF, Xu ZG, Guo J (2013) Adsorption of $\mathrm{Pb}^{2+}, \mathrm{Cd}^{2+}$ and $\mathrm{Zn}^{2+}$ from aqueous solution by modified sugarcane bagasse. Res Chem Intermed 41:1525-1541

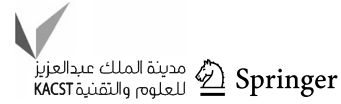


Yurlova L, Kryvoruchko A, Kornilovich B (2002) Removal of Ni(II) ions from wastewater by miceller-enhanced ultrafilteration. Desalination 144:255-260

Zabel T (1984) Flotation in water treatment. In: Ives KJ (ed) The scientific basis of flotation. Martinus Nijhoff Publishers, The Hague, pp 349-378

Zamboulis D, Peleka EN, Lazaridis NK, Matis KA (2011) Metal ion separation and recovery from environmental sources using various flotation and sorption techniques. J Chem Technol Biotechnol 86:335-344

Zheng L, Danga Z, Yia X, Zhanga H (2010) Equilibrium and kinetic studies of adsorption of $\mathrm{Cd}(\mathrm{II})$ from aqueous solution using modified corn stalk. J Hazard Mater 176:650-656
Zheng L, Zhu C, Dang Z, Zhang H, Yi X, Liu C (2012) Preparation of cellulose derived from corn stalk and its application for cadmium ion adsorption from aqueous solution. Carbohydr Polym 90:1008-1015

Zhu CS, Waref LP, Chen W (2009) Removal of $\mathrm{Cu}$ (II) from aqueous solution by agricultural by products-peanut hull. J Hazard Mater 186:739-746

Zuo XJ, Balasurbramanian R, Fu DF, Li H (2012) Biosorption of copper, zinc and cadmium using sodium hydroxide immersed Cymbopogon schoenanthus L. Spreng (Lemon grass). Ecol Eng 49:186-189 